\title{
Winter severity and snowiness and their multiannual variability in the Karkonosze Mountains and Jizera Mountains
}

\author{
Grzegorz Urban $^{1}$ • Dáša Richterová ${ }^{2}$ - Stanislava Kliegrová ${ }^{3}$ - Ilona Zusková ${ }^{4}$. \\ Piotr Pawliczek ${ }^{5}$
}

Received: 24 May 2017 / Accepted: 4 September 2017 /Published online: 15 September 2017

(C) The Author(s) 2017. This article is an open access publication

\begin{abstract}
This paper analyses winter severity and snow conditions in the Karkonosze Mountains and Jizera Mountains and examines their long-term trends. The analysis used modified comprehensive winter snowiness (WSW) and winter severity (WOW) indices as defined by Paczos (1982). An attempt was also made to determine the relationship between the WSW and WOW indices. Measurement data were obtained from eight stations operated by the Institute of Meteorology and Water Management - National Research Institute (IMGW-PIB), from eight stations operated by the Czech Hydrological and Meteorological Institute (CHMI) and also
\end{abstract}

\section{Grzegorz Urban}

grzegorz.urban@imgw.pl; urbag@poczta.onet.pl

Dáša Richterová

dasar@chmi.cz

Stanislava Kliegrová

stanislava.kliegrova@chmi.cz

Ilona Zusková

zuskova@chmi.cz

Piotr Pawliczek

piotr.pawliczek@uwr.edu.pl

1 Institute of Meteorology and Water Management - National Research Institute, Podleśna Street 01-673, 61 Warsaw, Poland

2 Czech Hydrometeorological Institute, branch office Ústí nad Labem, Kočkovská 18, 40011 Ústí nad Labem, Czechia

3 Czech Hydrometeorological Institute, branch office Hradec Králové, Dvorská 410, 50311 Hradec Králové, Czechia

4 Czech Hydrometeorological Institute, branch office Praha, Na Šabatce 17, 4 - Komořany, 14306 Praha, Czechia

5 Institute of Geography and Regional Development, University of Wrocław, Uniwersytecki Pl. 1, 50-137, Wrocław, Poland from the Meteorological Observatory of the University of Wrocław (UWr) on Mount Szrenica. Essentially, the study covered the period from 1961 to 2015. In some cases, however, the period analysed was shorter due to the limited availability of data, which was conditioned, inter alia, by the period of operation of the station in question, and its type.

Viewed on a macroscale, snow conditions in the Karkonosze Mountains and Jizera Mountains (in similar altitude zones) are clearly more favourable on southern slopes than on northern ones. In the study area, negative trends have been observed with respect to both the WSW and WOW indices - winters have become less snowy and warmer. The correlation between the WOW and WSW indices is positive. At stations with northern macroexposure, WOW and WSW show greater correlation than at ones with southern macroexposure. This relationship is the weakest for stations that are situated in the upper ranges (Mount Śnieżka and Mount Szrenica).

\section{Introduction}

Among the basic research problems in modern climatology is that of establishing climate trends and variability, including in the winter period, through the analysis of winter severity and snowiness. Snow cover and its multiannual trends are the result of the direct or indirect simultaneous impact of multiple climate components and factors and of their changes in subsequent years (Foster et al. 1983; Falarz 2004). Any changes in snow cover thickness and retention time may have longlasting environmental and economic implications (Beniston 1997, 2000; Beniston et al. 2003). Economic losses related to snow cover deficits are of particular importance in mountain areas where a significant proportion of tourism income is derived from winter sports (Beniston 2000). The climate 
changes predicted to take place until 2050, i.e. progressive warming, will cause a gradual decrease in the surface area of glaciers and in snow cover; the snow line and vegetation zones will move upwards and northwards (IPCC 2001, 2013; Migała 2005). It is estimated that in mountain regions, an average increase in air temperatures of $1{ }^{\circ} \mathrm{C}$ may be accompanied by an upward shift in the snow line of around $150 \mathrm{~m}$ (Haeberli and Beniston 1998). The results of snow cover studies confirm its high sensitivity to climate change and to individual climate components (Cayan 1996; Bednorz 2004; Stewart et al. 2005) as well as to progressive warming (Karl et al. 1993; Dettinger and Cayan 1995; Stewart et al. 2004; Hidalgo et al. 2009).

This topic is particularly salient, because the increase in mean annual air temperatures is most affected by the temperature of winter months (Hess 1974; Trepińska 1976; Wibig and Głowicki 2002; Piotrowicz 2006; Rebetez and Reinhard 2008; Kliegrová et al. 2009). The progressive warming results in shorter winters and earlier spring thaws (Bednorz 2004; Migała et al. 2016). The phenomenon of snowy or severe winters is of interest to many people and institutions, e.g. in connection with the considerable damage these can wreak in many economies (Beniston et al. 2003; Bednorz 2008, 2013; Kulasová and Bubeníčková 2009).

The issue of winter snowiness and severity is a complex one, and it is insufficient to apply just a single criterion to its assessment (Piasecki 1995; Piotrowicz 2004; Mayes Boustead et al. 2015). Hence, several criteria are usually used simultaneously to classify and assess winters (Domonkos and Piotrowicz 1998; Piotrowicz 2006). The overwhelming majority of research deals with the severity of winters in terms of temperature (Obrebka-Starklowa et al. 1995; Piotrowicz 1997; Twardosz and KossowskaCezak 2016), and to a lesser extent with winter snowiness and snow cover variability in the mountains (Jackson 1977; Piasecki 1995; Falarz 2000-2001; Lapin et al. 2007; Príbullová et al. 2009; Urban 2016). Far fewer articles discuss winter temperatures and snow conditions at the same time (Paczos 1982, 1985; Niedźwiecki 1998; Janasz 2000; Majewski et al. 2011). Describing the winter characteristics in the Karkonosze Mountains and Jizera Mountains is a difficult task due to the considerable variability of weather conditions in the temperate transitional climate zone in which both mountain ranges are located. Hence, there is considerable intraseasonal and long-term variability between winters (Majewski et al. 2011). In turn of interseasonal variability of weather conditions is a typical feature of the Karkonosze Mountains climate and is determined primarily by the zonal atmospheric circulation that forms over the North Atlantic. This is clearly illustrated by the fact that temperature conditions on Mount Śnieżka are dependent on the North Atlantic Oscillation (NAO) index (Sobik et al. 2014; Migała et al. 2016).
The purpose of this study is to analyse the severity and snowiness of winters and to examine their long-term trends in the Karkonosze Mountains and Jizera Mountains on the Polish and Czech sides of both mountain ranges. Additionally, attempts have been made to determine the relationship between winter severity and snowiness. Among the motivations for conducting research on this theme was the fact that to date, literature on the subject lacks a comprehensive, methodologically uniform study that would cover such a long period and use a larger number of stations in the Western Sudetes on both sides of the Polish-Czech border. The studies already published have concerned the comparison of snow conditions on both sides of the border in the context of skiing opportunities (Urban and Richterová 2010) or were case studies (Ojrzyńska et al. 2010; Urban et al. 2011), but no analysis of long-term trends or assessment of winter conditions was offered.

\section{Source data and methods}

The measurement data used in this paper were obtained from meteorological stations of the Institute of Meteorology and Water Management - National Research Institute (IMGWPIB), from the Czech Hydrological and Meteorological Institute (CHMI) and from the Meteorological Observatory of the University of Wrocław (UWr) on Mount Szrenica (Fig. 1; Table 1). The source material consisted of daily mean, minimum, and maximum air temperature values, and daily depths of snow cover on the ground at 06.00 UTC. The basic research period included 55 consecutive winter seasons (winters) from the 1961/1962-2015/2016 multiannual period. In some cases, the period analysed was shorter (Table 1). This resulted from the availability of data, which was conditioned by, inter alia, the operation of the station in question, changes in station type (climatological, rain gauge) and thus the number of meteorological parameters measured. The choice of stations was primarily guided by their suitability for assembling long data series and the completeness of their measurement sequences. In addition, the stations were selected so that there were no significant changes in their locations and so that they represented the different altitude zones present in the Karkonosze Mountains and Jizera Mountains.

The authors wanted to document the distinct snow and temperature conditions on the southern and northern slopes of the Karkonosze Mountains and Jizera Mountains as reflected by winter severity and snowiness as accurately as possible. For this reason, all the reliable materials available have been used, starting from 1961. Nevertheless, winter severity and snowiness indices were calculated for a uniform period consisting of the 30 consecutive seasons from $1981 / 1982$ to $2010 / 2011$, and measurements from fewer stations were used. It is worth stressing that the results obtained 


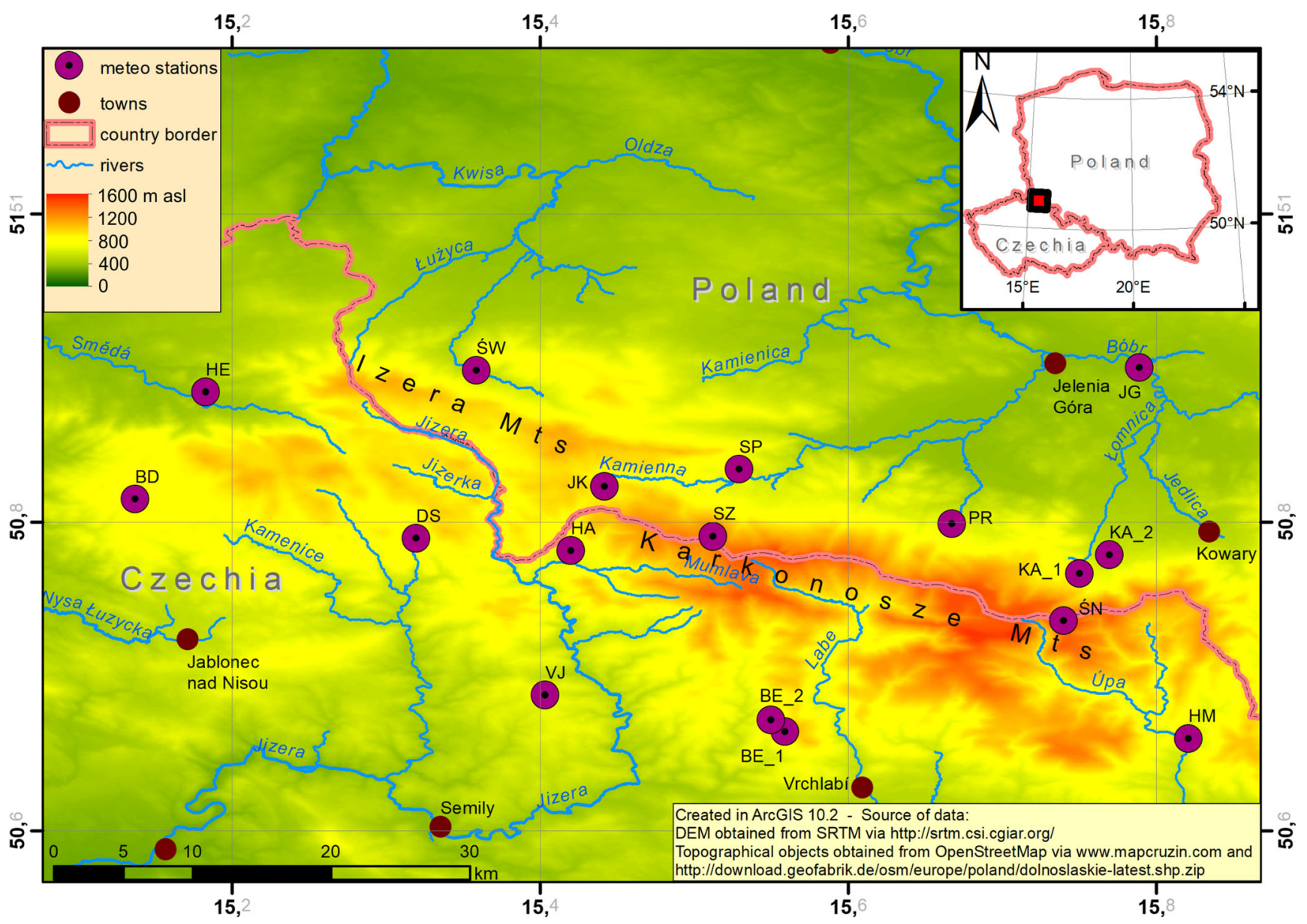

Fig. 1 Locations of the measurement stations used in the study. Station name abbreviations as per Table 1

were similar to those for the periods of different lengths (from 15 to 55 years) described in Table 1. The calculations included 9 out of 13 stations in the case of the winter severity index and 11 out of 16 stations in the case of the winter snowiness index. Studies covering 30 -year periods form the basis for determining the climate characteristics of individual areas, and the 1981-2010 multiannual period is currently recommended for analysis purposes by the World Meteorological Organisation and is the so-called standard or reference period (WMO 2011). A similar approach, using data series of different lengths, was applied to snow cover studies in Austria (Hantel et al. 2000) and in the mountains of Bulgaria (Brown and Petkova 2007).

This approach is consistent with the accepted view that even mean 10-year values of individual meteorological parameters can be used to capture the spatial diversity of climate and make it possible to detect general patterns that govern the phenomenon in question (Hess 1965; Hess et al. 1980). Other authors report that the optimal period for reliably determining mean air temperature for a station that has a data series significantly shorter than 30 years ranges from 5 to 15 years (Huang et al. 1996) or from 5 to 20 years for extreme temperature values (Srivastava et al. 2003). Huang et al. (1996) stated that if mean values are to be determined, the exact length of the period adopted for this purpose within the 10-30 year range is not significant. In turn, Sansom and Tait (2004) believe that using shorter data series in local studies of temperature and precipitation fields significantly improves the quality of the results obtained for the study area compared to the use of simple spatial interpolation. Using the example of stations located on the northern and southern slopes of the Alps, Marty (2008) demonstrated that when analysing long-term mean values, there is considerable similarity between snow cover characteristics at stations located at comparable altitudes. This is present despite the possible lack of homogeneity caused by the changes in station locations and the different characteristics of their locations.

In the case of snow cover, there are unlikely to be any breaks in the homogeneity of the multiannual measurement series. This is due to the simplicity of the measurement and the fact that observation timing and methods have not changed since World War II (Falarz 2006). A change in station location appears to be the only threat to the homogeneity of such series (Falarz 2006). The snow cover measurement methodology 


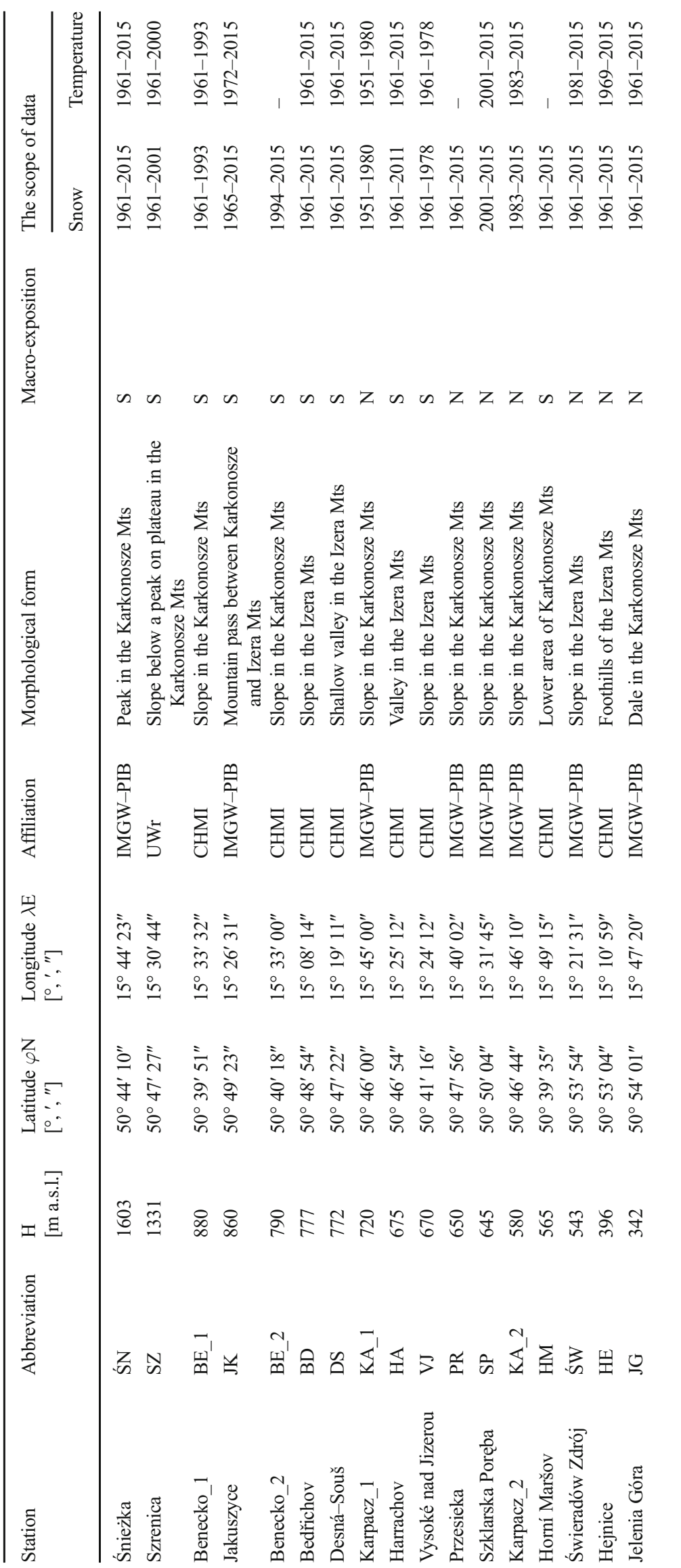


was uniform at all the stations analysed and was in line with the guidelines for the National Hydrological and Meteorological Service of the Institute of Meteorology and Water Management (IMGW) (Janiszewski 1988). A similar measurement methodology is used at the CHMI (Lipina et al. 2014). In the paper, stations whose location changed significantly were treated as stations with two separate measurement series and were labelled accordingly, e.g. Karpacz_1 and Karpacz_2 or Benecko_1 and Benecko_2 (Table 1). Therefore, the snow cover data series used should be considered homogeneous. Small gaps in data series that were present for some stations were eliminated using the arithmetic means method on the basis of measurement data from the nearest stations that represented similar climatic and morphological conditions.

Since IMGW-PIB and CHMI calculate mean daily air temperatures in different fashions, a uniform method was used. Namely, the mean daily temperature $(\mathrm{T})$ was determined for all stations according to the following formula: $\mathrm{T}=(\mathrm{Tmax}+$ Tmin)/2, where:

Tmax maximum daily air temperature $\left[{ }^{\circ} \mathrm{C}\right]$;

Tmin minimum daily air temperature $\left[{ }^{\circ} \mathrm{C}\right]$.

This method was used successfully in previous studies of trends in air temperature (Migała et al. 2016; Urban and Tomczyński 2017). The characteristics of various methods for determining mean air temperatures, and the differences between them were presented by Urban $(2010,2013)$.

In the study, winter was assumed to last from 1 November to 30 April of the following year. This definition of winter stemmed from the fact that during the aforementioned months, weather conditions typical of this season, i.e. snow cover and negative air temperatures, are present in the mountains, as well as from the method adopted for defining winter. The only exception was that analyses of the start and end dates for snow cover were performed from 1 August of year X to 31 July of year $X+1$. This was due to the fact that in the upper range of the Karkonosze Mountains (Mount Śnieżka—1603 m a.s.l.; Mount Szrenica-1331 m a.s.l.), snow cover on the ground sometimes even occurs in summer months. This approach has already been applied before (Falarz 2000-2001; Urban 2015, 2016).

A day with snow cover was assumed to be a day on which snow depth measured at 6.00 UTC was not less than $1 \mathrm{~cm}$ and snow covered at least $50 \%$ of the area. This limitation made it possible to eliminate days on which snow fell but conditions were not conducive to snow cover forming. This condition mainly applies to the period of snow cover formation and disappearance. The adoption of this assumption made it possible to clearly define characteristic periods (number of days with snow cover and potential period) and their start and end dates.
Winter temperature and snowiness have been described in terms of the fundamental climatological characteristics of these meteorological parameters. A synthesis of those characteristics was presented by Paczos (1982) for the climatic conditions prevailing in Poland, including in mountain areas, in the form of indices describing winter severity and snowiness (from December to March). These indices have been used in this paper with minor modifications.

The winter severity index (WOW) formula developed by Paczos (1982) has the following form:

$$
\begin{aligned}
\mathrm{WOW} & =(1-0.25 \times \mathrm{Tw}) \times 0.8325+0.0144 \times \mathrm{NDw} \\
& +0.0087 \times \mathrm{NDf}+0.0045 \times N D v f-0.0026 \times \mathrm{ST}
\end{aligned}
$$

where:

WOW winter severity index;

Tw mean winter air temperature $\left({ }^{\circ} \mathrm{C}\right)$;

$\mathrm{NDw}$ number of winter days (with mean daily temperature $\leq 0{ }^{\circ} \mathrm{C}$ );

NDf number of ice days (with maximum temperature $<0{ }^{\circ} \mathrm{C}$ );

NDvf number of very frosty days (with minimum temperature $<-10{ }^{\circ} \mathrm{C}$ );

ST sum of mean daily temperature values $<0^{\circ} \mathrm{C}$.

Values of the winter severity index range from 0 to 10 , where 0 denotes the mildest winter and 10 the coldest one. In the formula above, the modification proposed by Janasz (2000) was introduced. The modification of Paczos's (1982) formula consisted of defining very frosty days as days with a maximum temperature (rather than minimum temperature as suggested by Paczos) below $-10^{\circ} \mathrm{C}$. Majewski et al. (2011) had previously made a similar decision. In addition, a winter day was assumed to be a day with a mean temperature lower than $0{ }^{\circ} \mathrm{C}$ rather than lower than or equal to $0{ }^{\circ} \mathrm{C}$ (as proposed by Paczos). The changes adopted are in line with the current definition of a very frosty day and of a winter day (Niedźwiedź et al. 2003; ČMeS 2016).

The winter snowiness index (WSW) was also calculated using a formula proposed by Paczos (1982):

$\mathrm{WSW}=0.0328 \times N D S C+0.0246 \times N D S C 20+0.00012 \times \mathrm{SSC}$

where:

WSW winter snowiness index ranging from 0 to 10 ; NDSC number of days with snow cover $\geq 1 \mathrm{~cm}$ deep; NDSC20 number of days with snow cover $>20 \mathrm{~cm}$ deep; SSC sum of snow cover depths in $\mathrm{cm}$.

In the formula above, a modification was introduced to change the sign before the threshold value from $>20$ to $\geq 20 \mathrm{~cm}$. Whereas in the winter severity formula, the assumption that winter lasts from November to April rather than from December to March as in the original (Paczos 1982) does not 
change the number of classes $(0-10)$, this is not the case with the snowiness formula. Namely, extending the original winter period by 2 months increases the number of classes to 15 . This results from the fact that the winter snowiness formula contains the sum of snow cover thickness (depth) during the period analysed. Therefore, the addition of two more months (November and April) results in an increase in the number of classes by $50 \%$.

Using average multiannual values of the winter severity (WOWavg) and snowiness (WSWavg) indices and their standard deviations $(\delta)$, three groups of winters have been distinguished both in terms of severity and snowiness. From the point of view of their severity, winters have been divided into:

1. frosty $($ WOW $\geq$ WOWavg $+\delta$ );

2. moderately frosty (WOWavg $-\delta<$ WOW $<$ WOWavg $+\delta$ );

3. mild $($ WOW $\leq$ WOWavg $-\delta)$,

while from the point of view of snowiness, they have been divided into:

1. snowy (WSW $\geq$ WSWavg $+\delta$ );

2. moderately snowy (WSWavg $-\delta<\mathrm{WSW}<\mathrm{WSWavg}+$ $\delta)$;

3. with little snow $(\mathrm{WSW} \leq \mathrm{WSWavg}-\delta)$.

The boundaries between the groups have been determined separately for each station (see Tables 2 and 4).

The division presented made it possible to transform an absolute classification into a relative one. Thus, it enabled a comparison to be made between individual winters at a single measurement station throughout the entire period. A similar approach to winter classification based on average multiannual values of these indices and their standard deviations was used in earlier work (Paczos 1982; Janasz 2000; Majewski et al. 2011; Twardosz and Kossowska-Cezak 2016). For stations with at least a 30 -year measurement data series, trends in winter severity, and snowiness were also determined. Student's $t$ test was used to verify the statistical significance of those trends at the $p<0.05$ significance level.

A comprehensive index that combined, inter alia, air temperature, total snowfall, snow cover depth, and the duration of the winter season has been successfully applied in studies of winter severity and associated trends in the US (Mayes Boustead et al. 2015).

\section{Results and discussion}

\subsection{Winter severity}

Average values of the WOW winter severity index in the study area range from about 6-7 (moderate winters) in the upper ranges of the Karkonosze Mountains (Mount Śnieżka, Mount Szrenica) to around 2 (winters with little snow) at the foot of the Jizera Mountains (Hejnice). As concerns extreme values, the WOW index at all the stations analysed ranged from 0.0 (for the 2006/2007 season in Hejnice) to 9.2 (for the 1969/1970 season on Mount Śnieżka). In general, the distribution of WOW index values correlates with the absolute altitude of each station and is directly proportional to it (Fig. 2). The higher the WOW index value, the more severe the winter in temperature terms. However, there are some deviations from this general pattern that result from the local landform and the location of the station in question. An example is the Jelenia Góra station, which is located in a large midmountain basin and is characterised by frequent and intense air temperature inversions (Głowicki 1970; Hess et al. 1980). On 10 February 1956, in a Stevenson screen situated $2 \mathrm{~m}$ above ground level at that station, the absolute minimum air temperature recorded at meteorological stations in Poland in the post-World War II period was measured at $-36.9{ }^{\circ} \mathrm{C}$ (Kuziemska 1983). This is the reason why the WOW index for that station is significantly higher than indicated by its altitude above sea level (Figs. 2-3). The WOW value for Jelenia Góra is close to WOW values for stations situated 200 to 300 m higher (Świeradów Zdrój, Karpacz_2, or Szklarska Poręa). This means that in this case, the change in air temperature as a function of altitude above sea level is considerably distorted at locations that are situated close to one another. In this case, thermal conditions at the station in question are affected more by the landform than by its exposure to the sun (or lack thereof).

The influence of solar radiation and exposure and also of the landform on air temperatures in the Polish Sudetes as reflected by different values of vertical temperature gradient in different seasons was described by Schmuck (1969). This issue was also noted in later studies that described the topoclimate of the Jizera Mountains (Sobik and Urban 2000; Urban 2002) or the climate of the Karkonosze Mountains (Sobik et al. 2014). Also of note are the relatively higher WOW index values at CHMI stations that are situated around $670 \mathrm{~m}$ a.s.l. (Harrachov, Vysoké nad Jizerou) when compared to the stations situated on the northern (Polish) side of the mountains at similar altitudes (Szklarska Poreba). The difference in favour of CHMI stations amounts to approximately one WOW class on average (Figs. 2-3). In this case, the differentiating factor is the exposure of the station in question to the advections of air masses from the south, southwest, and west that prevail in winter $(\mathrm{S}, \mathrm{SW}$, and $\mathrm{W}$ macroexposure). For example, the share of winds from the S, SW, and W directions for the November-April period in the years 1961-1990 on Mount Śnieżka (the highest peak in the Sudetes) was $55.4 \%$ in total (12.3, 23.0, and 20.1\%, respectively) (Głowicki 1995). 
Table 2 Values of the winter severity index and its standard deviation $(\delta)$, coefficient of variation $(\mathrm{CV})$, and frequency of severe and mild winters $(\mathrm{N})$

\begin{tabular}{|c|c|c|c|c|c|c|c|c|c|c|c|c|c|}
\hline Winter & $\begin{array}{r}\text { Śnieżka } \\
{[1603 \mathrm{~m}]}\end{array}$ & $\begin{array}{l}\text { Szrenica } \\
{[1331 \mathrm{~m}]}\end{array}$ & $\begin{array}{c}\text { Benecko_1 } 1 \\
{[880 \mathrm{~m}]}\end{array}$ & $\begin{array}{c}\text { Jakuszyce } \\
{[860 \mathrm{~m}]}\end{array}$ & $\begin{array}{c}\text { Bedřichov } \\
{[777 \mathrm{~m}]}\end{array}$ & $\begin{array}{c}\text { Desná- } \\
\text { Souš } \\
{[772 \mathrm{~m}]}\end{array}$ & $\begin{array}{c}\text { Harrachov } \\
{[675 \mathrm{~m}]}\end{array}$ & $\begin{array}{c}\text { Vysoké } \\
\text { nad } \\
\text { Jizerou } \\
{[670 \mathrm{~m}]}\end{array}$ & $\begin{array}{c}\text { Szklarska } \\
\text { Poręba } \\
{[645 \mathrm{~m}]}\end{array}$ & $\begin{array}{c}\text { Karpacz_2 } \\
{[580 \mathrm{~m}]}\end{array}$ & $\begin{array}{c}\text { Świeradów } \\
\text { Zdrój } \\
\text { [543 m] }\end{array}$ & $\begin{array}{l}\text { Hejnice } \\
{[396 \mathrm{~m}]}\end{array}$ & $\begin{array}{c}\text { Jelenia } \\
\text { Góra } \\
{[342 \mathrm{~m}]}\end{array}$ \\
\hline $1961 / 62$ & 8.1 & 7.1 & 5.1 & & 5.3 & 6.0 & 4.6 & 4.1 & & & & & 3.2 \\
\hline $1962 / 63$ & 9.2 & 8.2 & 6.2 & & 6.7 & 7.4 & 5.9 & 5.4 & & & & & 5.6 \\
\hline $1963 / 64$ & 7.1 & 6.4 & 5.2 & & 5.2 & 5.6 & 5.1 & 4.6 & & & & & 4.0 \\
\hline $1964 / 65$ & 8.1 & 7.1 & 4.8 & & 4.6 & 4.9 & 4.1 & 4.0 & & & & & 3.3 \\
\hline $1965 / 66$ & 7.7 & 6.7 & 4.2 & & 4.3 & 4.5 & 3.7 & 3.6 & & & & & 2.8 \\
\hline $1966 / 67$ & 7.8 & 6.8 & 4.7 & & 4.6 & 4.5 & 3.5 & 3.2 & & & & & 2.0 \\
\hline $1967 / 68$ & 7.8 & 6.7 & 4.7 & & 4.7 & 4.7 & 3.8 & 3.3 & & & & & 2.6 \\
\hline $1968 / 69$ & 7.6 & 6.6 & 5.5 & & 5.6 & 5.5 & 5.0 & 4.5 & & & & & 3.8 \\
\hline $1969 / 70$ & 9.2 & 8.0 & 6.1 & & 6.3 & 6.3 & 5.7 & 5.4 & & & & 3.9 & 4.6 \\
\hline $1970 / 71$ & 7.3 & 6.3 & 4.2 & & 4.3 & 4.1 & 3.7 & 3.3 & & & & 2.0 & 2.8 \\
\hline $1971 / 72$ & 6.9 & 5.7 & 3.6 & & 3.4 & 3.1 & 2.8 & 2.6 & & & & 1.4 & 1.8 \\
\hline $1972 / 73$ & 7.1 & 6.2 & 4.1 & 5.2 & 4.6 & 4.3 & 3.2 & 3.4 & & & & 1.4 & 1.8 \\
\hline $1973 / 74$ & 6.7 & 5.7 & 3.4 & 4.3 & 3.5 & 3.6 & 2.6 & 2.5 & & & & 0.8 & 1.4 \\
\hline $1974 / 75$ & 6.5 & 5.5 & 2.9 & 3.6 & 3.0 & 2.8 & 2.4 & 1.8 & & & & 0.4 & 0.7 \\
\hline $1975 / 76$ & 8.2 & 7.5 & 5.2 & 5.9 & 5.2 & 4.8 & 4.3 & 3.9 & & & & 2.3 & 2.9 \\
\hline $1976 / 77$ & 7.3 & 6.3 & 3.8 & 4.4 & 4.0 & 4.0 & 3.5 & 3.2 & & & & 1.5 & 2.1 \\
\hline $1977 / 78$ & 7.4 & 6.6 & 4.7 & 5.1 & 4.5 & 4.4 & 3.7 & 3.7 & & & & 1.5 & 2.1 \\
\hline $1978 / 79$ & 7.5 & 6.7 & 4.6 & 5.4 & 4.9 & 4.7 & 4.1 & 3.9 & & & & 2.4 & 3.1 \\
\hline $1979 / 80$ & 7.7 & 6.7 & 4.6 & 5.2 & 4.5 & 4.4 & 3.6 & & & & & 1.7 & 2.4 \\
\hline $1980 / 81$ & 7.9 & 6.9 & 5.4 & 5.5 & 4.8 & 4.7 & 4.2 & & & & & 2.3 & 2.8 \\
\hline $1981 / 82$ & 8.1 & 7.1 & 4.9 & 5.8 & 5.3 & 5.4 & 4.5 & & & & 2.9 & 2.4 & 3.0 \\
\hline $1982 / 83$ & 6.7 & 5.7 & 3.3 & 3.9 & 3.5 & 3.3 & 2.6 & & & & 1.6 & 0.9 & 1.6 \\
\hline $1983 / 84$ & 8.2 & 7.0 & 5.0 & 5.6 & 5.3 & 4.8 & 4.4 & & & 3.0 & 2.8 & 1.8 & 2.7 \\
\hline $1984 / 85$ & 8.2 & 7.1 & 5.3 & 5.9 & 5.6 & 5.3 & 4.9 & & & 3.5 & 3.5 & 2.9 & 3.8 \\
\hline $1985 / 86$ & 8.4 & 7.3 & 5.1 & 5.7 & 5.0 & 4.8 & 4.5 & & & 3.5 & 3.6 & 2.9 & 3.6 \\
\hline $1986 / 87$ & 8.1 & 7.0 & 5.7 & 5.8 & 5.6 & 5.4 & 5.1 & & & 3.8 & 3.9 & 3.2 & 3.8 \\
\hline $1987 / 88$ & 7.2 & 5.9 & 4.4 & 4.1 & 3.7 & 3.7 & 3.0 & & & 1.5 & 1.9 & 1.0 & 1.3 \\
\hline $1988 / 89$ & 5.7 & 4.8 & 3.9 & 3.5 & 3.1 & 3.1 & 2.8 & & & 1.0 & 0.9 & 0.7 & 1.1 \\
\hline $1989 / 90$ & 5.4 & 4.1 & 2.8 & 3.2 & 2.6 & 2.7 & 2.6 & & & 0.9 & 1.0 & 0.6 & 1.3 \\
\hline $1990 / 91$ & 7.3 & 6.1 & 4.2 & 4.6 & 4.0 & 3.9 & 3.5 & & & 2.4 & 2.5 & 1.7 & 2.2 \\
\hline $1991 / 92$ & 6.7 & 5.6 & 3.8 & 4.2 & 3.6 & 3.6 & 2.8 & & & 1.7 & 2.0 & 1.3 & 1.7 \\
\hline $1992 / 93$ & 6.6 & 5.4 & 4.2 & 4.7 & 4.1 & 4.2 & 3.2 & & & 2.1 & 2.3 & 1.6 & 2.4 \\
\hline $1993 / 94$ & 7.2 & 6.1 & 4.5 & 4.1 & 3.5 & 3.6 & 2.6 & & & 1.8 & 1.9 & 1.4 & 1.8 \\
\hline $1994 / 95$ & 6.8 & 5.7 & & 3.7 & 3.1 & 3.2 & 2.3 & & & 1.3 & 1.4 & 0.9 & 1.4 \\
\hline $1995 / 96$ & 8.1 & 7.0 & & 7.1 & 6.3 & 6.3 & 5.1 & & & 4.8 & 4.6 & 4.0 & 5.0 \\
\hline $1996 / 97$ & 7.0 & 6.0 & & 5.2 & 4.8 & 4.7 & 4.3 & & & 2.8 & 3.0 & 2.3 & 3.3 \\
\hline $1997 / 98$ & 6.1 & 4.9 & & 3.6 & 2.8 & 2.9 & 2.5 & & & 1.4 & 1.4 & 0.9 & 1.5 \\
\hline $1998 / 99$ & 7.0 & 6.0 & & 4.7 & 3.8 & 3.9 & 3.5 & & & 2.2 & 2.2 & 1.9 & 2.4 \\
\hline $1999 / 00$ & 7.4 & 6.3 & & 4.5 & 3.9 & 4.0 & 3.3 & & & 1.6 & 1.8 & 1.1 & 1.7 \\
\hline $2000 / 01$ & 6.2 & 5.1 & & 3.6 & 3.2 & 3.4 & 2.8 & & & 1.5 & 1.6 & 1.1 & 1.7 \\
\hline $2001 / 02$ & 6.8 & & & 4.3 & 3.9 & 3.8 & 3.2 & & 2.5 & 2.1 & 2.1 & 1.8 & 2.2 \\
\hline $2002 / 03$ & 7.1 & & & 5.5 & 5.3 & 4.8 & 4.0 & & 3.3 & 3.2 & 3.1 & 2.5 & 3.6 \\
\hline $2003 / 04$ & 6.9 & & & 4.5 & 4.7 & 4.1 & 3.3 & & 2.4 & 2.3 & 2.3 & 1.6 & 2.2 \\
\hline $2004 / 05$ & 7.1 & & & 5.0 & 4.5 & 4.7 & 3.9 & & 3.1 & 2.7 & 2.3 & 2.0 & 2.6 \\
\hline $2005 / 06$ & 7.7 & & & 6.4 & 5.8 & 6.0 & 4.4 & & 3.9 & 3.8 & 3.7 & 2.9 & 3.9 \\
\hline $2006 / 07$ & 5.0 & & & 1.9 & 1.5 & 1.6 & 0.8 & & 0.4 & 0.1 & 0.3 & 0.0 & 0.2 \\
\hline $2007 / 08$ & 6.5 & & & 3.7 & 3.3 & 3.4 & 2.4 & & 1.1 & 1.3 & 1.7 & 0.9 & 1.3 \\
\hline $2008 / 09$ & 6.6 & & & 4.2 & 3.8 & 4.0 & 2.7 & & 2.1 & 1.9 & 1.9 & 1.5 & 2.0 \\
\hline $2009 / 10$ & 7.4 & & & 4.9 & 4.5 & 4.7 & 3.9 & & 3.4 & 3.3 & 3.1 & 2.5 & 3.3 \\
\hline $2010 / 11$ & 6.8 & & & 5.0 & 4.4 & 4.5 & 3.7 & & 3.1 & 2.7 & 2.8 & 2.4 & 3.3 \\
\hline $2011 / 12$ & 6.6 & & & 4.5 & 3.6 & 3.9 & 3.0 & & 2.6 & 2.0 & 1.9 & 1.6 & 2.2 \\
\hline $2012 / 13$ & 7.6 & & & 5.6 & 4.8 & 4.9 & 4.4 & & 4.2 & 3.4 & 3.5 & 2.9 & 3.3 \\
\hline $2013 / 14$ & 4.9 & & & 2.2 & 1.8 & 1.9 & 1.4 & & 0.7 & 0.3 & 0.5 & 0.2 & 0.6 \\
\hline $2014 / 15$ & 6.1 & & & 3.5 & 2.8 & 2.7 & 2.1 & & 1.7 & 1.3 & 1.3 & 0.8 & 1.0 \\
\hline $2015 / 16$ & 5.7 & & & 3.2 & 2.6 & 2.5 & 1.9 & & 1.2 & 0.8 & 1.0 & 0.6 & 1.0 \\
\hline Average & 7.2 & 6.3 & 4.5 & 4.6 & 4.3 & 4.3 & 3.5 & 3.7 & 2.4 & 2.2 & 2.2 & 1.7 & 2.5 \\
\hline$\delta$ & 0.89 & 0.85 & 0.84 & 1.05 & 1.11 & 1.13 & 1.04 & 0.92 & 1.17 & 1.09 & 1.01 & 0.91 & 1.12 \\
\hline $\mathrm{CV}[\%]$ & 12.5 & 13.4 & 18.5 & 22.8 & 26.0 & 26.5 & 29.3 & 24.9 & 49.1 & 49.8 & 45.1 & 53.3 & 45.4 \\
\hline $\begin{array}{c}\text { N_Severe } \\
\text { winters [\%] }\end{array}$ & 20.0 & 10.0 & 15.2 & 15.9 & 12.7 & 16.4 & 14.5 & 16.7 & 13.3 & 21.2 & 17.1 & 14.9 & 18.2 \\
\hline $\begin{array}{c}\text { N_Mild } \\
\text { winters [\%] }\end{array}$ & 14.5 & 15.0 & 15.2 & 20.5 & 16.4 & 16.4 & 14.5 & 16.7 & 26.7 & 15.2 & 14.3 & 17.0 & 16.4 \\
\hline
\end{tabular}

Explanations:

a blue field indicates a severe (cold) winter $(\mathrm{WOW} \geq \mathrm{WOWavg}+\delta$ );

a red field indicates a mild (warm) winter (WOW $\leq$ WOWavg- $\delta$ );

a white field indicates a moderate winter in terms of temperature (WOWavg- $\delta<$ WOW $<$ WOWavg $+\delta$ ).

The blue field indicates a severe (cold) winter (WOW $\geq$ WOWavg $+\delta$ ). The red field indicates a mild (warm) winter $($ WOW $\leq$ WOWavg $-\delta)$. The white field indicates a moderate winter in terms of temperature (WOWavg $-\delta<$ WOW $<$ WOWavg $+\delta$ )

Slope exposure to circulation from the aforementioned directions, which prevails in winter, exerts a clear influence on determining the winter temperature and precipitation field on the Karkonosze Mountains, as demonstrated by Sobik et al.
(2014). Apart from atmospheric circulation, the orientation of the main ridge of the Karkonosze Mountains (along the WNW-ESE axis) is a secondary factor affecting the thermal characteristics of air masses around this massif. During 
Fig. 2 Average (Avg), maximum (Max), and minimum (Min) values of the winter severity index (WOW) at the stations analysed

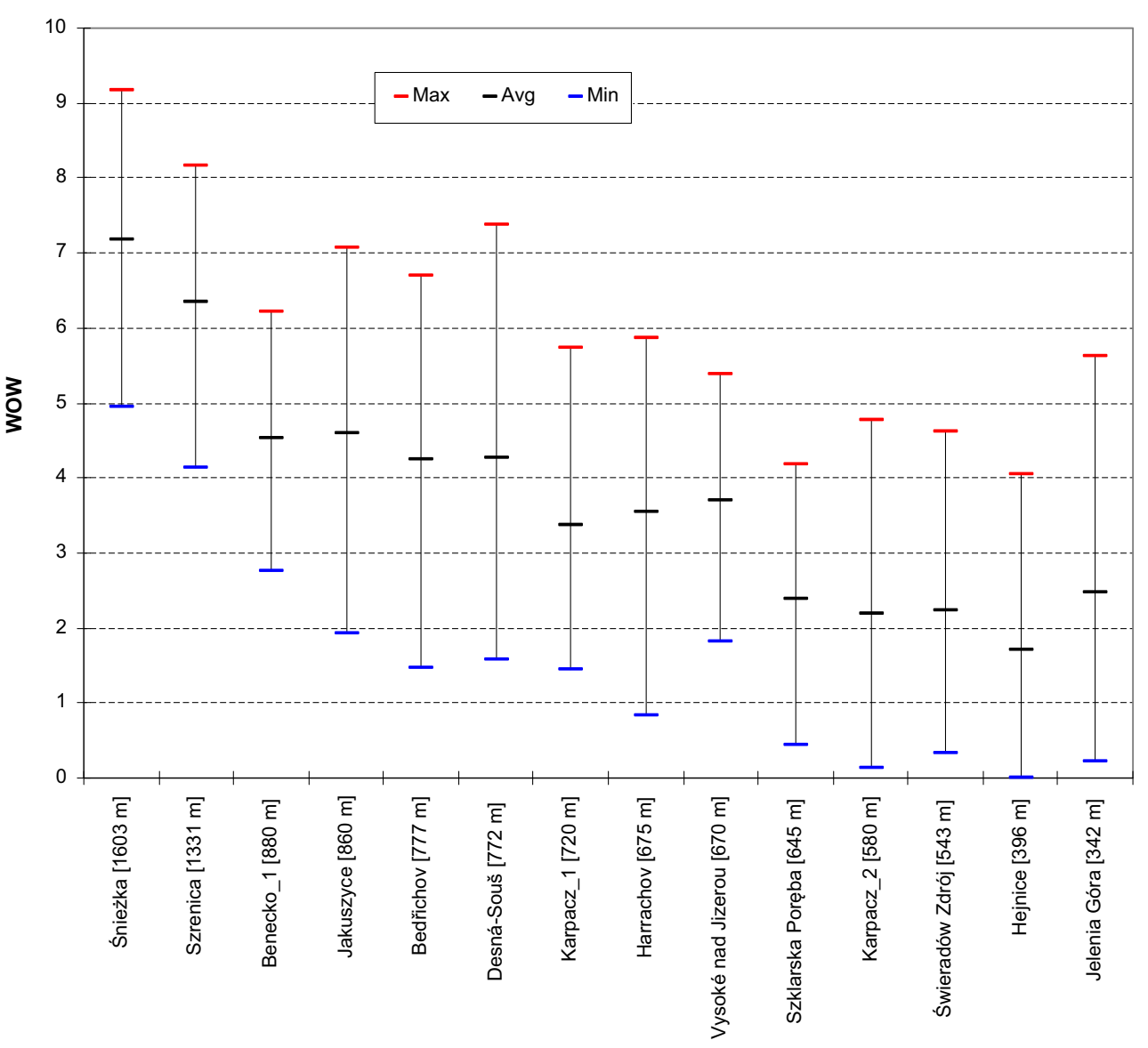

station advection from the southwest or southern directions, the stations located on the Polish (leeward) side of the Karkonosze Mountains are subject to the warming effect of catabatic foehn winds (Kwiatkowski 1972, 1975, 1979). The air moving downslope on the leeward side of the mountains is heated adiabatically. Thus, the foehn contributes, inter alia, to raising mean winter temperatures at stations on leeward (northern) slopes compared to stations on the windward (southern) slopes at the same altitudes. During the winter months, at altitudes ranging from 600 to $800 \mathrm{~m}$ a.s.l., the northern slopes of the Karkonosze Mountains and Jizera Mountains are around $0.5-1.0^{\circ} \mathrm{C}$ warmer than the southern slopes (Sobik
Fig. 3 The relationship between station altitude $(\mathrm{H})$ and the average WOW index value for southern $(\mathrm{S})$ and northern $(\mathrm{N})$ macroexposures

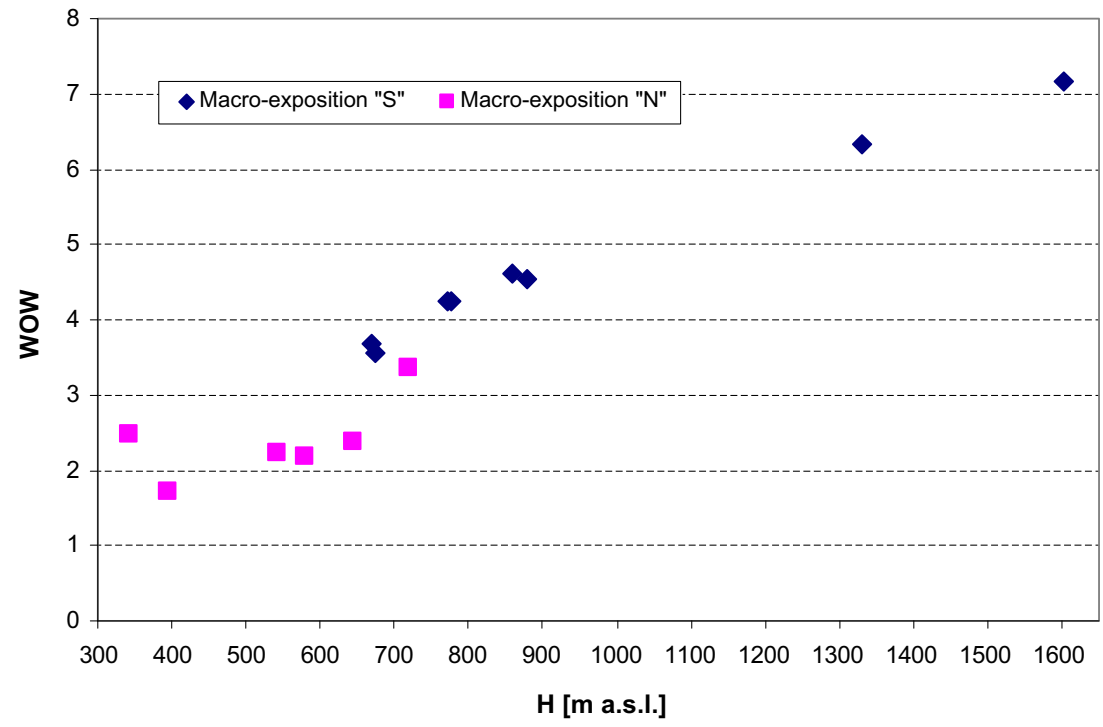


Fig. 4 Average (Avg), maximum (Max), and minimum (Min) values of the winter severity index (WOW) at selected stations

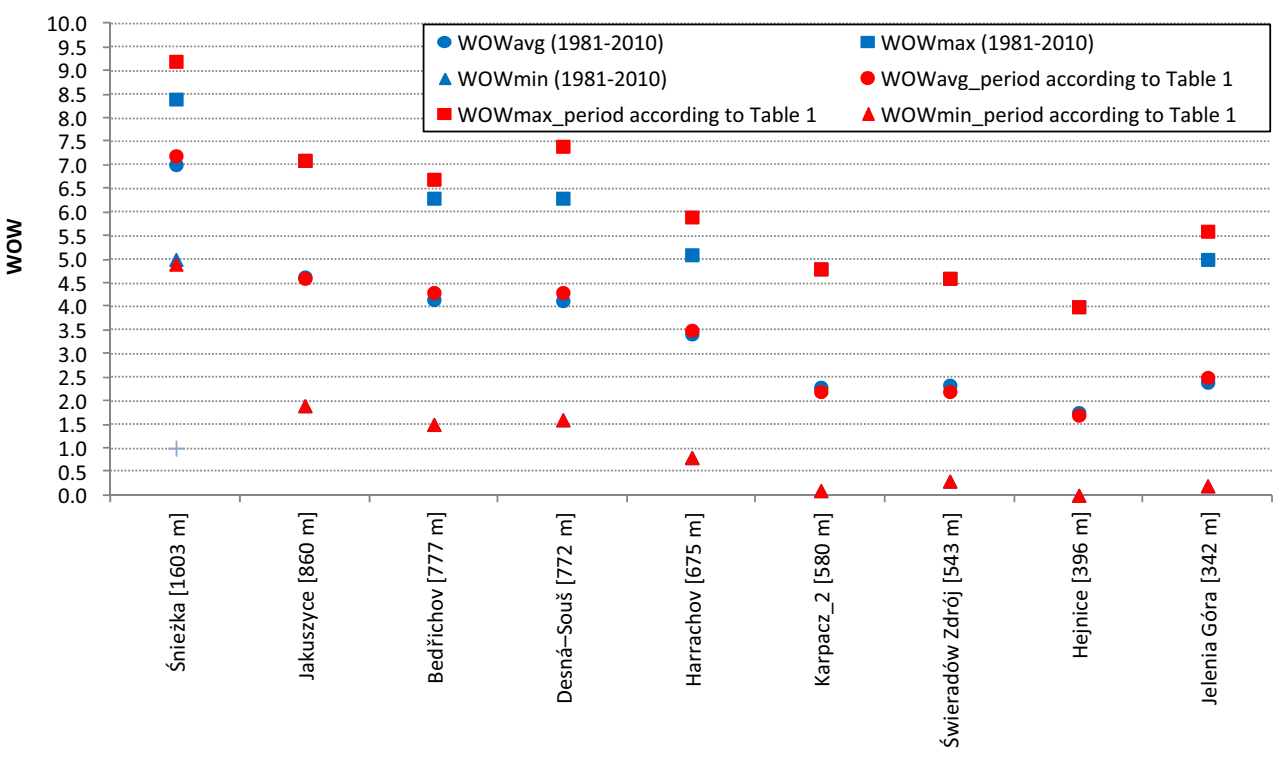

station et al. 2009). The difference in mean air temperatures in winter between stations on opposite sides of the mountain ridge increases together with the difference in altitude between the ridge and the station in question. Owing to the influence of foehn winds and its location at the bottom of a large basin, Jelenia Góra experiences alternating waves of freezing and thawing of varying durations and exhibiting thermal anomalies to various degrees (Głowicki 1993).

The relationships observed for various periods at the stations analysed, which have been described above and presented graphically (Figs. 2-3), are confirmed by the results obtained for the 1981-2010 period at selected stations (methodological justification presented in Chapter 2). The average WOW index values (illustrating climate patterns) at stations for the period 1981-2010 are almost identical with those for the periods presented in Table 1 . The same is true for minimum index values as those occurred in the 2001-2010 period at most stations. Only in a few cases were the maximum WOW values for the 1961-2015 period slightly higher than that for 1981-2010, since the maximum values were recorded in the 1960s (Fig. 4).

\subsubsection{Temporal and spatial differences and trends}

The winter severity calendar, developed on the basis of multiannual severity index averages (WOWavg) and standard deviations, demonstrates that moderately frosty winters predominated at all the stations analysed. In addition, since the late 1980s, the winters' thermal characteristics have changed compared to earlier decades of the twentieth century. The prevalence of mild winters has increased, while frosty winters have become less frequent. The pattern found is consistent with the results obtained for Europe, where in the second half of the 1951-2010 period, an increase in the frequency of exceptionally mild winters was observed at the expense of exceptionally cold ones (Twardosz and Kossowska-Cezak 2016). In the last two or three decades, an increase in the frequency of warm winters has also been recorded in the Swiss Alps (Scherrer et al. 2004; Marty 2008) and the USA (Mayes Boustead et al. 2015).

In the last 10 years, frosty winters were virtually absent (except for a few locations with northern exposure). The warmest winters within the altitude profile found in the Karkonosze Mountains and Jizera Mountains were 1988/1989-1989/1990, 2006/2007, and 2013/2014-2015/ 2016 (Table 2). The winter of 2006/2007 was extremely warm, with the WOW index reaching its lowest values at all stations (WOW $\leq$ WOWavg $-2 \times \delta$ ) - from around 0.0 at the foot of the mountains to just 5.0 in the upper ranges of the Karkonosze Mountains. The winter of 2006/2007 was exceptionally warm in most parts of Europe (Luterbacher et al. 2007; Twardosz and Kossowska-Cezak 2016). Winters with high WOW indices at most stations were 1962/1963, 1968/1969-1969/1970, 1984/1985-1986/1987, 1995/1996, and 2005/2006. The highest WOW values noted in those winters (from 4.0 in Hejnice to 9.2 on Mount Śnieżka) were recorded in 1962/1963 and 1995/1996. During those winters, the highest WOW values for the multiannual period analysed were observed at all individual stations (Table 2). High WOW index values were present in the winter of 1995/1996 at most stations in Poland (Olba-Ziety and Grabowski 2007), whereas the winter of 1962/1963 was exceptionally cold in most of Europe (Twardosz and Kossowska-Cezak 2016).

The variability of the WOW index as expressed by its standard deviation ranges from approx. 0.8-0.9 at the stations situated at the highest altitudes above sea level to approx. 1.1-1.2 in the lower zones. The dispersion of WOW values is much better illustrated by the coefficient of variation $(\mathrm{CV})$, 
Table 3 Trend magnitude, correlation coefficient (R), and statistical significance of the WOW and WSW indices

\begin{tabular}{|c|c|c|c|c|c|c|c|c|}
\hline \multirow[t]{2}{*}{ Station } & \multicolumn{2}{|c|}{ Tendency/10 years } & \multicolumn{2}{|l|}{$R$} & \multicolumn{2}{|c|}{ Number of seasons } & \multicolumn{2}{|c|}{ Significant statistic at the 0.05 significance level } \\
\hline & WOW & WSW & WOW & WSW & WOW & WSW & WOW & WSW \\
\hline Śnieżka & -0.312 & -0.042 & 0.559 & 0.047 & 55 & 55 & Yes & No \\
\hline Szrenica & -0.367 & -0.235 & 0.506 & 0.169 & 40 & 42 & Yes & No \\
\hline Benecko_1 & -0.258 & -0.324 & 0.297 & 0.187 & 33 & 33 & No & No \\
\hline Jakuszyce & -0.253 & -0.382 & 0.310 & 0.312 & 44 & 51 & Yes & Yes \\
\hline Bedřichov & -0.302 & -0.354 & 0.437 & 0.292 & 55 & 55 & Yes & Yes \\
\hline Desná-Souš & -0.307 & -0.279 & 0.436 & 0.235 & 55 & 55 & Yes & No \\
\hline Harrachov & -0.303 & -0.182 & 0.468 & 0.153 & 55 & 51 & Yes & No \\
\hline Przesieka & - & -0.156 & - & 0.161 & - & 55 & - & No \\
\hline Karpacz_2 & -0.265 & -0.197 & 0.236 & 0.128 & 33 & 33 & No & No \\
\hline Horní Maršov & - & -0.502 & - & 0.392 & - & 55 & - & Yes \\
\hline Świeradów Zdrój & -0.241 & -0.333 & 0.245 & 0.359 & 33 & 55 & No & Yes \\
\hline Hejnice & -0.099 & -0.108 & 0.149 & 0.157 & 47 & 55 & No & No \\
\hline Jelenia Góra & -0.229 & -0.156 & 0.328 & 0.211 & 55 & 55 & Yes & No \\
\hline
\end{tabular}

which is the ratio of the standard deviation to the mean expressed as a percentage. $\mathrm{CV}$ values indicate that the greatest variation in the WOW index is present at the foot of the mountains and the smallest in their upper ranges. CV is inversely proportional to a station's absolute altitude (Table 2). The upper ranges of the Karkonosze Mountains have thermal characteristics that are more similar to an oceanic climate compared to the lower zones; this manifests itself in smaller air temperature amplitudes in individual months of the year (Sobik et al. 2014), which in turn translates into lower variability of the WOW index. Trends in the WOW index calculated for all stations analysed in the Karkonosze Mountains and Jizera Mountains are negative (Table 3). This means that WOW values gradually declined, thus indicating a progressive increase in air temperatures and in individual thermal indicators (WOW components), and consequently, climate warming. Rates of decline of the WOW index ranged from approx. $-0.1 / 10$ years in Hejnice to approx. $-0.4 / 10$ years on Mount Szrenica. The average WOW decline rate for all stations amounted to $-0.27 / 10$ years. WOW trends are statistically significant at the 0.05 significance level for 7 out of the 11 stations selected for the purposes of analysing thermal conditions (Table 3). Similar negative trends, which are mostly statistically insignificant at the 0.05 level, have been observed for many thermal characteristics of the cold season in Central Europe (Domonkos and Piotrowicz 1998). In the period 1881-2010 in the upper ranges of the Karkonosze Mountains, a decline was observed in the annual number of days with mean daily air temperatures below $0.0{ }^{\circ} \mathrm{C}$ and also in the number of extremely cold months, with a simultaneous increase in the number of very warm months in individual decades. This has been especially noticeable since the early 1990s (Migała et al. 2016). The higher frequency of mild winters may be related to the change in atmospheric circulation macrotypes over the North Atlantic. In the last decades of the twentieth century, an increase in cyclonic zonal circulation from the southwest was observed (Migała 2005; Migała et al. 2016). In Western and Central Europe, this type of circulation generates an extensive zone of weather fronts with heavy clouds, and also brings warming in the cold season and precipitation.

\subsection{Winter snowiness}

Average values of the WSW in the Karkonosze Mountains and Jizera Mountains range from approx. 2.5-3.0 (winters with little snow) in the lowest locations to approx. 10.0-10.5 (moderately snowy winters) in the upper ranges. With extreme values, the situation is similar. The lowest values of approx. 0.6 are observed in the locations with the lowest altitudes above sea level (Jelenia Góra, Hejnice), and the highest ones of approx. 13.0 at the stations situated at the highest altitudes (Mount Śnieżka, Mount Szrenica).

The significant difference in altitude, exceeding $1250 \mathrm{~m}$ (from Jelenia Góra, which lies in a basin, to the highest peak-Mount Śnieżka), and the variety of landforms and station exposures result in a clear spatial variation of WSW index values. The average WSW index values show greater variation (Figs. 4-5) than average WOW index values (Fig. 2).

The spatial variability of snowiness in winter results from multiple factors, including altitude above sea level and the orographic deformation of the field through which air masses flow that shape precipitation and air temperatures. As a result of this deformation, there is a clear contrast in snow conditions 
Fig. 5 Average (Avg), maximum (Max), and minimum (Min) values of the winter snowiness index (WSW) at the stations analysed

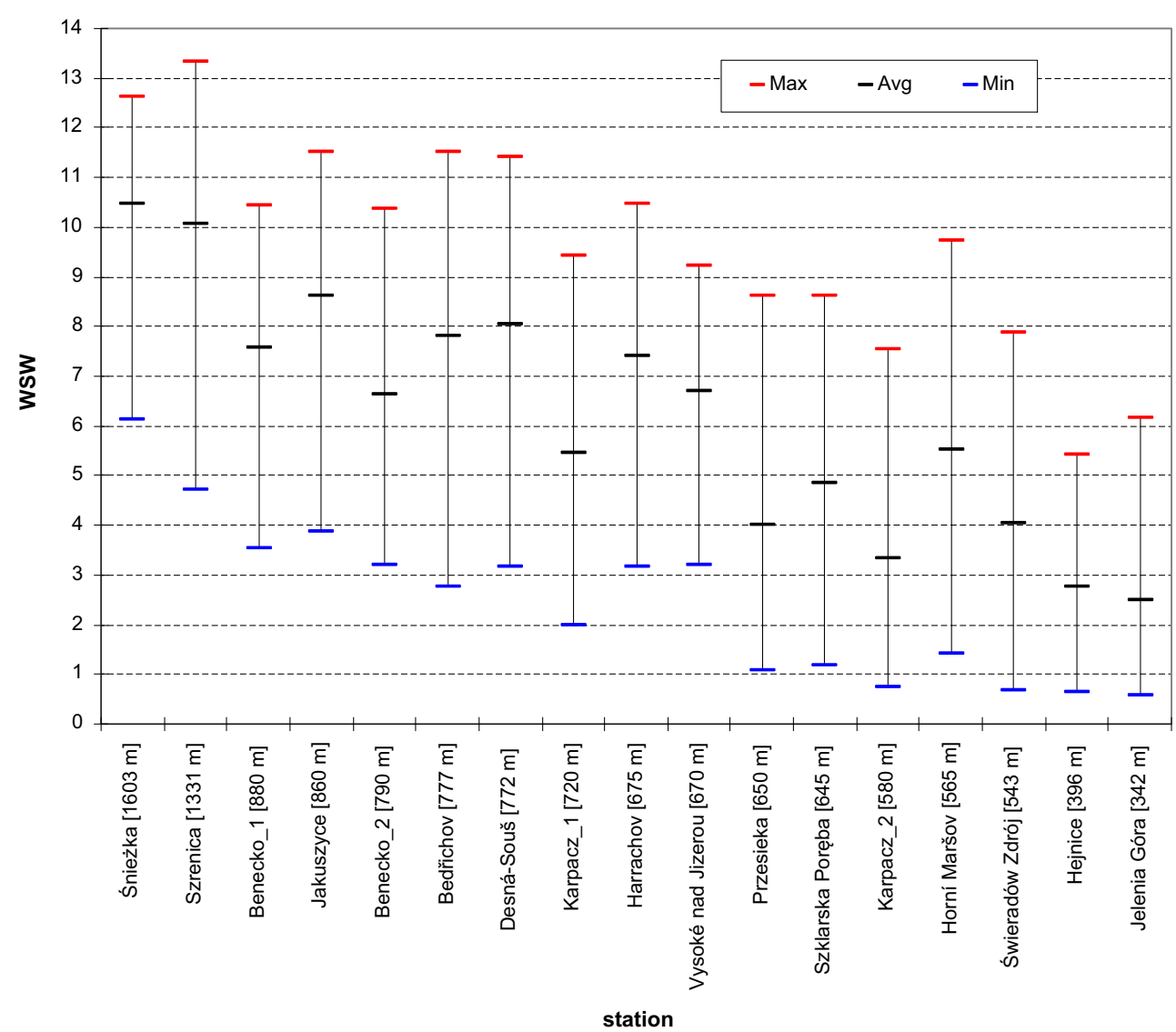

between the catchment of the Elbe River (S, SW, and W macroexposure) relative to the catchment of the Odra River (NE and $\mathrm{N}$ macroexposure). Areas with SW and $\mathrm{W}$ macroexposures are characterised by longer snow cover retention times and greater snow cover depths. On average, the snow conditions prevailing in the slope zone in the Elbe
River catchment are assessed at around 2-3 WSW classes higher than those on the northern slope of the mountains in the Odra River catchment. This contrast is especially clear within the 500-900 $\mathrm{m}$ a.s.l. range, which is evidenced, inter alia, by average WSW index values for the following stations: Harrachov versus Szklarska Poręba, Przesieka or Horní
Fig. 6 The relationship between station altitude $(\mathrm{H})$ and the average WSW index value for southern (S) and northern (N) macroexposures

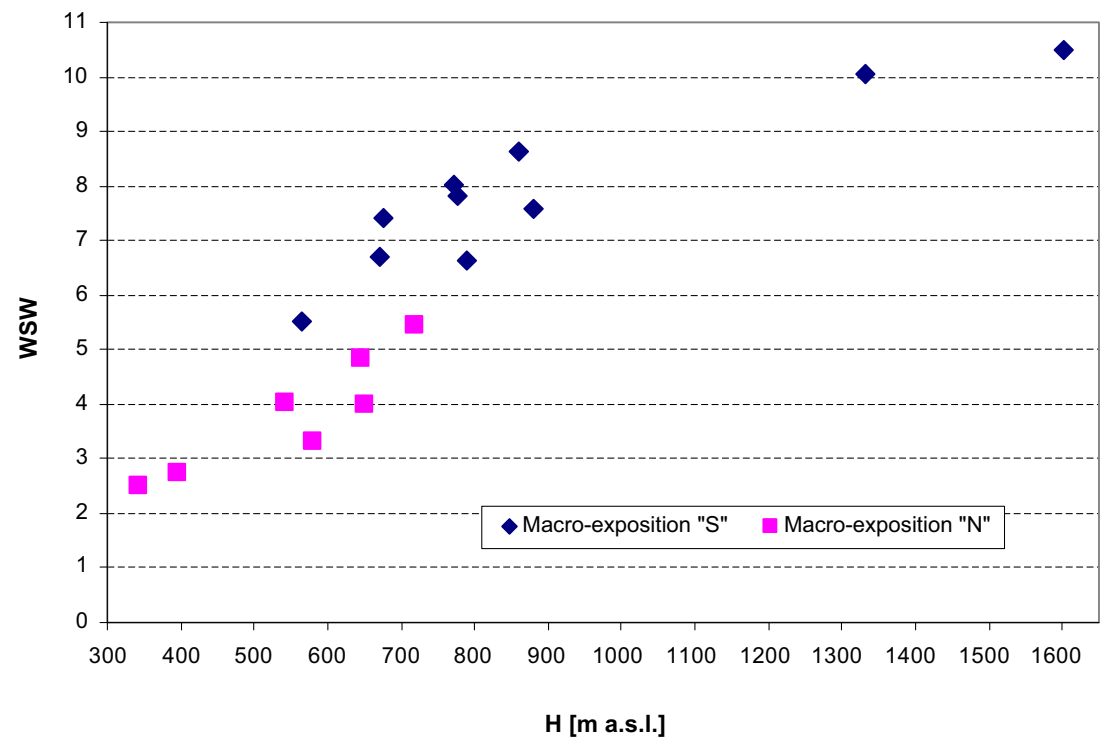


Maršov versus Karpacz_2 (Figs. 5-6). The difference in winter snowiness between slopes with southern macroexposure compared to slopes with northern macroexposure corresponds to an altitude difference of around $250 \mathrm{~m}$. Thus, the snow conditions typical of the slope zone in the Elbe River catchment are present in the Odra River catchment at altitudes that are approx. $250 \mathrm{~m}$ higher. This result is consistent with the earlier studies of snow cover in the Western Sudetes (Sobik et al. 2009; Urban and Richterová 2010) and of temperature and precipitation variations in the Karkonosze Mountains (Sobik et al. 2014). In upper mountain ranges, the differences are blurred owing to the frequent alternating movement of snow, which is carried by the wind from one side of the massif to the other.

The fact that the main differences in precipitation at comparable absolute altitudes in the Karkonosze Mountains are not present in the east-west direction but rather between the southern and northern sides of the mountains was noted by Sobik et al. (2014). Sobik emphasised the increase in winter precipitation in the upper catchment of the Kamienna River in the western part of the Polish Karkonosze. This effect is caused by the weakness of descending air currents during southern circulation, which results from the relatively low altitude of the Main Ridge of the Karkonosze Mountains to the west of Mount Szrenica and the presence of the only slightly lower Upper Ridge of the Jizera Mountains that lies parallel to the Karkonosze Mountains and hinders the flow of foehn currents (Kwiatkowski 1985). Similarly, Falarz (2002) demonstrated a greater effect of the meridional component of atmospheric circulation as compared to the zonal one and also the significant role of the foehn effect in the determining of nival conditions and their variability in the Polish Tatra Mountains. The decrease in the number of days with snow cover observed at stations below $1300 \mathrm{~m}$ a.s.l. in the Swiss Alps at the end of the twentieth century was also due to the increase in air temperature and macrocirculation associated with the North Atlantic Oscillation (NAO). NAO is the factor that accounts for the difference in numbers of days with snow cover between the northern and southern slopes of the Alps (Scherrer et al. 2004).

The relationships observed for various periods at the stations analysed, which have been described above and presented graphically (Figs. 5-6), are confirmed by the results obtained for the 1981-2010 period at selected stations (methodological justification presented in Chapter 2). The average WSW index values (illustrating climate patterns) noted for stations for the 1981-2010 period are, just as in the case of the WOW index, almost identical with those for the periods presented in Table 1. Only in a few cases were the maximum and minimum WSW index values for the period presented in Table 1 slightly higher or lower, respectively, than in the 1981-2010 period, since the maximum values were recorded in the 1960s and the minimum ones in the years 2001-2010 (Fig. 7).

\subsubsection{Temporal and spatial differences and trends of the winter snowiness index}

The winter snowiness calendar developed on the basis of the multiannual snowiness index averages (WSWavg) and standard deviations demonstrates that moderately snowy winters predominated at all the stations analysed. In addition, the winters' thermal characteristics have changed since the late 1980s and early 1990s. The prevalence of winters with little snow has increased everywhere except for Mount Śnieżka while snowy winters have become less frequent. This was particularly pronounced in the last 10 years when virtually no snowy winters were present. Winters with little snow in the Karkonosze Mountains and Jizera Mountains were 1989/1990-1990/1991, 1997/1998, 2000/2001, 2006/2007, and 2013/2014-2015/2016 (Table 4). During the winter of $2006 / 2007$, extremely little snow was present, with the WSW index reaching the lowest values at nearly all stations (WSW $\leq \mathrm{WSWavg}-2 \times \delta$ ) - from around 0.6-0.7 at the foot of the mountains to 8.7 in the upper ranges of the Karkonosze Mountains. The conditions were very similar during the winters of 2013/2014 and 2015/2016, which at the same time were also exceptionally warm winters. The decrease in depth of snow cover and its retention time since the late 1980s has also been characteristic of stations situated at lower altitudes in the Alps (Laternser and Schneebeli 2003; Scherrer et al. 2004; Marty 2011). That trend was noticeable at stations both on the northern and southern slopes of the Swiss Alps (Marty 2008). The decline could have been associated with extremely warm winters in the last two or three decades (Scherrer et al. 2004; Marty 2008), some of which, as with the 2006/2007 winter, appear to have been unique in Europe in the last 500 years (Luterbacher et al. 2007).

Winters with high WSW indices (snowy winters) at most stations were 1966/1967, 1969/1970, 1975/1976, 1981/1982, 1995/1996, and 2004/2005-2005/2006. Among the aforementioned winters, the highest WSW values (from 4.05.0 at the foot of the mountains to approx. 12.0 on Mount Śnieżka) were recorded in 1995/1996 and 2005/2006. During those winters, the highest WSW values for the multiannual period analysed were observed at nearly all individual stations (Table 4). High WSW index values were present in the winter of 1995/1996 at most stations in Poland (Olba-Zięty and Grabowski 2007) as well as in the Czech Republic (Němec and Zusková 2005). Occasionally, snowy winters only occur in the upper part of the altitude profile (1974/1975) or only in its bottom part (1962/1963).

Except for the lowest stations with northern macroexposure, the winter of $1978 / 1979$, which is referred to in Poland as "the winter of the century", did not make its mark (Majewski et al. 2011).

The variability of the WSW index as expressed by its standard deviation ranges from approx. 1.0-1.1 at the stations 
Fig. 7 Average (Avg), maximum (Max), and minimum (Min) values of the winter snowiness index (WSW) at selected stations

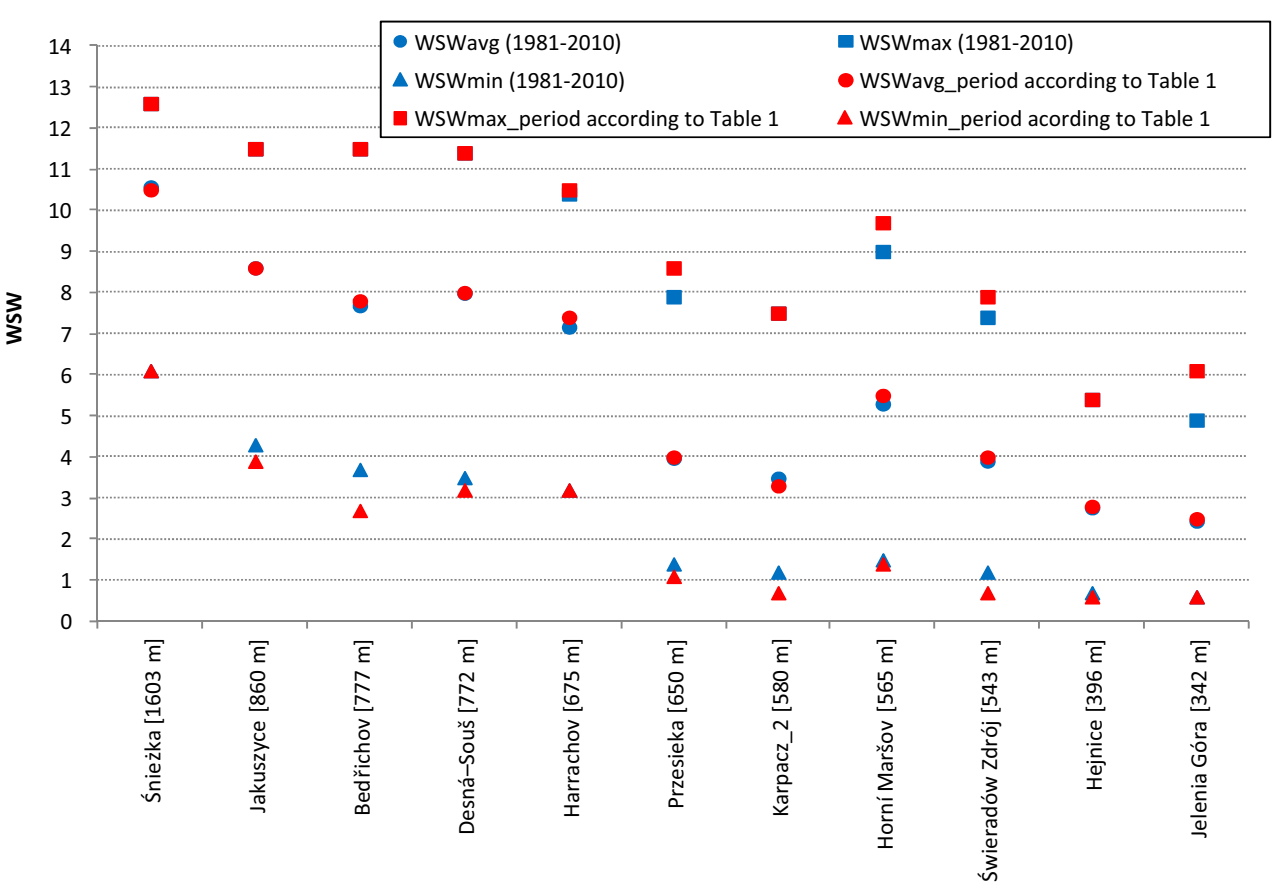

station situated at the lowest altitudes above sea level through approx. 1.4-1.7 in the upper ranges of the mountains to approx. 1.92.1 at slope stations. The dispersion of WSW values is better illustrated by the CV expressed as a percentage. It also allows for WSW comparisons to be made within a time series and also between stations. The smallest values (approx. 15\%) are present in the upper ranges, i.e. snow cover is the most stable there. The highest values of CV (approx. 45\%) are present at the lowest stations located at the foot of the mountains (Table 4). Thus, the coefficient of variation for the WSW index is inversely proportional to altitude above sea level. This result is consistent with earlier conclusions concerning the coefficient of variation of snow cover parameters in the Polish Tatras (Falarz 2000-2001) and in the Polish Sudetes (Urban 2015, 2016). Nevertheless, considerable differences in $\mathrm{CV}$ values for the WSW index are present within the broad slope zone. This is particularly pronounced in the 600-700 m a.s.l. zone where stations with southern macroeconomic exposure (Harrachov, Vysoké nad Jizerou) exhibit significantly lower WSW variability (approx. 25\%) than stations with northern macroeconomic exposure (Szklarska Poręba, Przesieka) (approx. 40\%).

Trends in the WSW index calculated for all stations analysed in the Karkonosze Mountains and Jizera Mountains are negative, just like those for the WOW index (Table 3). This means that WSW values decreased steadily, pointing to reduced snow cover retention times and depths (both parameters are components of WSW) during subsequent winters. This confirms the results of earlier studies on snow cover on Mount Śnieżka in the 1901-2000 period (Głowicki 2005) and in the Polish Sudetes together with their foreland in the 1951-2007 period (Urban 2015, 2016). Rates of decline of the WSW index ranged from approx. - 0.04/10 years on Mount Śnieżka to approx. $-0.38 / 10$ years in Jakuszyce. The average decline rate for all stations amounted to $-0.25 / 10$ years. WSW trends are statistically significant at the 0.05 significance level for just 4 out of the 13 stations selected for the purposes of analysing snowiness (Table 3 ). In the second half of the twentieth century, a slight downward trend in snow cover parameters was observed in most of Poland. Changes in snow cover are related to changes in atmospheric circulation, and in particular to the increased prevalence of advection of air masses from the western sector (Falarz 2004). Similarly, recent research from the Swiss Alps demonstrates that there was a downward trend in all snow cover parameters in the 1970-2015 period irrespective of the location of the station. For example, the downward trend in retention time averaged 8.9 days $/ 10$ years, and with respect to maximum thickness, it amounted to $10 \% / 10$ years on average. The shortened retention of snow cover in that area results primarily from its earlier disappearance (during spring thaws caused by higher spring temperatures) rather than its later appearance (Klein et al. 2016).

The direct cause of the decrease in the number of days with snow cover is the long-term change in air temperature and precipitation (Falarz 2004; Marty 2008). This mechanism may be confirmed in the first place by the pronounced upward trends in air temperatures in winter, both in Poland (Kożuchowski and Żmudzka 2001; Wibig and Głowicki 2002) and in Europe (Schönwiese and Rapp 1997). This fact is closely linked to the increase in the 
Table 4 Values of the winter snowiness index and its standard deviation $(\delta)$, coefficient of variation $(\mathrm{CV})$, and frequency of snowy winters and winters with little snow $(\mathrm{N})$

\begin{tabular}{|c|c|c|c|c|c|c|c|c|c|c|c|c|c|c|c|c|}
\hline Winter & $\begin{array}{c}\text { Śnieżka } \\
{[1603 \mathrm{~m}]}\end{array}$ & $\begin{array}{l}\text { Szrenica } \\
{[1331 \mathrm{~m}]}\end{array}$ & $\begin{array}{c}\text { Benecko } \\
-1[880 \\
\mathrm{m}]\end{array}$ & $\begin{array}{c}\text { Jakuszyc } \\
\text { e [860 } \\
\text { m] }\end{array}$ & $\begin{array}{c}\text { Benecko } \\
2[790 \\
\mathrm{m}]\end{array}$ & $\begin{array}{c}\text { Bedřicho } \\
\text { V } \\
{[777 \mathrm{~m}]}\end{array}$ & $\begin{array}{c}\text { Desná- } \\
\text { Souš } \\
{[772 \mathrm{~m}]}\end{array}$ & $\begin{array}{c}\text { Harracho } \\
\mathrm{v}[675 \\
\mathrm{m}]\end{array}$ & $\begin{array}{c}\text { Vysoké } \\
\text { n. } \\
\text { Jizerou } \\
{[670 \mathrm{~m}]}\end{array}$ & \begin{tabular}{|c} 
Przesiek \\
$\mathrm{a}[650$ \\
$\mathrm{m}]$
\end{tabular} & $\begin{array}{l}\text { Szklarsk } \\
\text { a Poręba } \\
{[645 \mathrm{~m}]}\end{array}$ & $\begin{array}{c}\text { Karpacz } \\
2[580 \\
\mathrm{m}]\end{array}$ & $\begin{array}{l}\text { Horní } \\
\text { Maršov } \\
{[565 \mathrm{~m}]}\end{array}$ & $\begin{array}{c}\text { Świerad } \\
\text { ów Zdrój } \\
{[543 \mathrm{~m}]}\end{array}$ & $\begin{array}{l}\text { Hejnice } \\
{[396 \mathrm{~m}]}\end{array}$ & $\begin{array}{c}\text { Jelenia } \\
\text { Góra } \\
{[342 \mathrm{~m}]}\end{array}$ \\
\hline $1961 / 62$ & 9.3 & 9.1 & 7.3 & & & 7.6 & 8.2 & 7.3 & 5.8 & 4.9 & & & 6.3 & 4.9 & 2.9 & 2.6 \\
\hline $1962 / 63$ & 10.8 & 9.9 & 9.1 & & & 9.2 & 9.3 & 8.3 & 8.2 & 6.8 & & & 8.0 & 6.8 & 5.1 & 5.4 \\
\hline $1963 / 64$ & 6.5 & 6.9 & 5.2 & & & 5.9 & 6.2 & 6.0 & 5.2 & 3.4 & & & 3.9 & 4.0 & 2.2 & 2.0 \\
\hline $1964 / 65$ & 11.1 & 10.9 & 8.8 & & & 8.2 & 8.6 & 7.8 & 6.8 & 4.4 & & & 7.0 & 4.7 & 3.5 & 3.6 \\
\hline $1965 / 66$ & 12.0 & 11.2 & 8.2 & 9.9 & & 8.9 & 9.7 & 8.8 & 6.5 & 3.8 & & & 7.5 & 3.9 & 3.3 & 3.4 \\
\hline $1966 / 67$ & 11.4 & 11.3 & 10.4 & 11.4 & & 10.1 & 10.8 & 10.3 & 8.4 & 3.8 & & & 8.7 & 5.1 & 2.2 & 2.3 \\
\hline $1967 / 68$ & 10.9 & 10.4 & 8.8 & 9.4 & & 9.4 & 9.9 & 8.5 & 8.1 & 3.4 & & & 7.4 & 5.0 & 3.0 & 2.8 \\
\hline $1968 / 69$ & 9.1 & 9.6 & 7.3 & 8.6 & & 7.6 & 8.3 & 7.6 & 7.0 & 4.1 & & & 6.2 & 5.2 & 2.3 & 2.7 \\
\hline $1969 / 70$ & 11.5 & 11.0 & 10.3 & 10.5 & & 10.7 & 11.0 & 10.5 & 9.2 & 8.6 & & & 9.7 & 7.9 & 5.2 & 6.1 \\
\hline $1970 / 71$ & 10.6 & 10.1 & 6.4 & 8.3 & & 7.5 & 7.2 & 6.7 & 4.5 & 4.1 & & & 4.3 & 3.8 & 3.2 & 3.1 \\
\hline $\begin{array}{l}1971 / 72 \\
\end{array}$ & 10.2 & 10.7 & 3.8 & 5.1 & & 4.4 & 3.4 & 3.3 & 3.2 & 2.7 & & & 3.3 & 2.4 & 1.7 & 1.9 \\
\hline $1972 / 73$ & 9.9 & 9.3 & 5.7 & 9.8 & & 8.9 & 7.6 & 5.2 & 5.1 & 3.1 & & & 3.9 & 3.9 & 1.9 & 1.4 \\
\hline $1973 / 74$ & 11.4 & 11.2 & 8.2 & 8.9 & & 8.4 & 8.6 & 8.4 & 7.4 & 2.6 & & & 7.3 & 3.3 & 1.3 & 1.3 \\
\hline $1974 / 75$ & 12.6 & 13.3 & 7.3 & 10.0 & & 7.5 & 8.6 & 8.1 & 5.5 & 2.1 & & & 3.4 & 2.4 & 0.9 & 0.7 \\
\hline $1975 / 76$ & 11.6 & 11.7 & 9.8 & 10.6 & & 10.4 & 10.5 & 9.6 & 8.8 & 4.8 & & & 7.7 & 4.4 & 2.5 & 2.1 \\
\hline $\begin{array}{l}1976 / 77 \\
\end{array}$ & 12.1 & 11.2 & 7.8 & 9.3 & & 9.4 & 8.4 & 7.5 & 6.3 & 3.8 & & & 4.6 & 4.1 & 3.2 & 3.0 \\
\hline $1977 / 78$ & 11.2 & 11.6 & 8.8 & 9.6 & & 10.0 & 9.4 & 8.7 & 7.7 & 5.7 & & & 8.3 & 5.0 & 2.7 & 1.7 \\
\hline $1978 / 79$ & 10.4 & 10.7 & 7.3 & 8.8 & & 9.2 & 8.1 & 7.3 & 6.7 & 5.1 & & & 6.5 & 5.9 & 4.6 & 4.2 \\
\hline $1979 / 80$ & 10.8 & 10.7 & 8.0 & 9.3 & & 8.9 & 8.9 & 7.4 & & 4.4 & & & 6.5 & 4.5 & 3.0 & 2.3 \\
\hline $1980 / 81$ & 8.0 & 9.0 & 6.8 & 7.9 & & 7.3 & 7.5 & 7.4 & & 3.7 & & & 5.8 & 4.7 & 3.7 & 3.4 \\
\hline $1981 / 82$ & 11.2 & 12.0 & 9.7 & 10.7 & & 11.2 & 10.7 & 9.5 & & 3.8 & & & 7.7 & 4.4 & 3.8 & 2.5 \\
\hline $1982 / 83$ & 9.7 & 9.6 & 6.4 & 8.6 & & 7.0 & 7.4 & 7.0 & & 3.4 & & & 4.3 & 3.0 & 2.3 & 2.2 \\
\hline $1983 / 84$ & 9.1 & 10.1 & 7.5 & 8.7 & & 8.8 & 8.3 & 7.8 & & 4.2 & & 2.8 & 6.6 & 4.5 & 2.3 & 1.4 \\
\hline $1984 / 85$ & 9.1 & 8.4 & 7.0 & 7.8 & & 7.5 & 7.1 & 6.7 & & 4.5 & & 4.0 & 5.7 & 4.4 & 3.6 & 2.8 \\
\hline $1985 / 86$ & 10.3 & 10.3 & 8.3 & 9.0 & & 8.6 & 8.6 & 7.8 & & 4.7 & & 3.9 & 6.5 & 4.2 & 3.3 & 3.0 \\
\hline $1986 / 87$ & 10.5 & 10.4 & 8.4 & 9.4 & & 9.1 & 9.2 & 8.6 & & 6.1 & & 5.4 & 8.1 & 6.5 & 4.3 & 3.3 \\
\hline $1987 / 88$ & 10.8 & 9.8 & 6.6 & 7.3 & & 6.7 & 7.1 & 6.3 & & 3.8 & & 3.5 & 4.3 & 3.9 & 2.7 & 1.7 \\
\hline $1988 / 89$ & 11.7 & 10.9 & 7.6 & 9.7 & & 7.8 & 7.9 & 7.8 & & 2.0 & & 1.4 & 4.2 & 1.6 & 1.1 & 1.0 \\
\hline $1989 / 90$ & 6.1 & 4.7 & 3.5 & 4.3 & & 3.7 & 3.5 & 3.6 & & 1.4 & & 1.2 & 2.3 & 1.7 & 1.1 & 0.7 \\
\hline $1990 / 91$ & 10.8 & 8.2 & 4.8 & 6.9 & & 5.2 & 6.1 & $\begin{array}{l}5.0 \\
5.4\end{array}$ & & 2.9 & & 2.8 & 3.0 & 3.0 & 2.4 & 2.1 \\
\hline $\begin{array}{l}1991 / 92 \\
\end{array}$ & 12.1 & 12.0 & 8.8 & 11.2 & & 9.8 & 9.8 & 9.1 & & 4.4 & & 3.8 & 7.2 & 4.3 & 2.4 & 2.4 \\
\hline $1992 / 93$ & 10.5 & 9.0 & 6.8 & 7.7 & & 6.8 & 7.6 & 6.5 & & 4.0 & & 3.7 & 5.1 & 4.1 & 3.1 & 2.8 \\
\hline $1993 / 94$ & 12.6 & 11.2 & 8.8 & 8.6 & & 7.0 & 8.6 & 7.9 & & 3.4 & & 2.9 & 7.5 & 3.6 & 2.4 & 2.0 \\
\hline $1994 / 95$ & 10.5 & 9.0 & & 7.8 & 6.8 & 6.7 & 7.8 & 6.3 & & 2.9 & & 2.8 & 5.4 & 3.3 & 2.4 & 2.0 \\
\hline $1995 / 96$ & 12.1 & 11.6 & & 11.5 & 10.4 & 10.8 & 10.7 & 10.2 & & 7.9 & & 6.8 & 9.0 & 7.4 & 4.3 & 4.9 \\
\hline $1996 / 97$ & 9.1 & 7.4 & & 8.8 & 7.1 & 7.8 & 7.8 & 7.1 & & 4.8 & & 4.1 & 5.1 & 4.3 & 2.6 & 2.7 \\
\hline $1997 / 98$ & 9.9 & 7.0 & & 5.6 & 3.3 & 4.4 & 3.9 & 3.2 & & 1.8 & & 2.1 & 1.9 & 2.3 & 1.6 & 1.5 \\
\hline $1998 / 99$ & 12.0 & 11.4 & & 10.3 & 8.7 & 8.6 & 9.6 & 8.8 & & 3.9 & & 3.3 & 6.1 & 3.9 & 2.9 & 2.8 \\
\hline $1999 / 00$ & 11.7 & 10.6 & & 10.3 & 7.9 & 8.5 & 9.0 & 8.5 & & 4.1 & & 3.3 & 6.2 & 4.1 & 2.6 & 1.9 \\
\hline $2000 / 01$ & 9.3 & 7.8 & & 7.1 & 3.6 & 5.4 & 6.6 & 5.4 & & 2.4 & & 2.4 & 3.4 & 3.3 & 1.5 & 1.7 \\
\hline $2001 / 02$ & 12.4 & 11.7 & & 9.7 & 6.2 & 7.7 & 8.6 & 7.9 & & 3.8 & 4.8 & 3.6 & 5.7 & 4.1 & 3.0 & 2.7 \\
\hline $2002 / 03$ & 10.5 & & & 8.5 & 6.7 & 7.6 & 7.2 & 6.4 & & 3.7 & 3.6 & 3.2 & 5.3 & 3.6 & 2.4 & 2.6 \\
\hline $2003 / 04$ & 11.1 & & & 8.4 & 6.3 & 7.2 & 8.0 & 7.2 & & 5.0 & 5.7 & 4.4 & 5.8 & 4.9 & 3.1 & 2.5 \\
\hline $2004 / 05$ & 12.6 & & & 11.0 & 8.8 & 9.6 & 10.1 & 9.5 & & 5.2 & 6.4 & 4.6 & 5.5 & 4.6 & 3.9 & 3.2 \\
\hline $2005 / 06$ & 11.8 & & & 11.1 & 10.2 & 11.5 & 11.4 & 10.4 & & 7.9 & 8.6 & 7.5 & 8.2 & 7.2 & 5.4 & 4.9 \\
\hline $2006 / 07$ & 8.7 & & & 5.5 & 3.7 & 4.2 & 4.5 & 3.7 & & 1.8 & 2.5 & 1.2 & 1.5 & 1.2 & 0.7 & 0.6 \\
\hline $2007 / 08$ & 11.4 & & & 8.4 & 6.4 & 7.3 & 8.6 & 5.1 & & 2.4 & 3.8 & 2.0 & 2.3 & 2.1 & 1.8 & 1.6 \\
\hline $2008 / 09$ & 10.8 & & & 9.2 & 7.7 & 9.5 & 9.2 & 7.8 & & 4.6 & 6.2 & 3.3 & 3.7 & 3.3 & 3.0 & 2.5 \\
\hline $2009 / 10$ & 9.9 & & & 6.6 & 6.3 & 6.5 & 6.8 & 6.0 & & 4.7 & 6.0 & 4.0 & 5.7 & 4.0 & 3.6 & 3.8 \\
\hline $2010 / 11$ & 8.8 & & & 8.4 & 7.1 & 8.0 & 7.9 & 7.4 & & 3.7 & 5.6 & 3.6 & 5.5 & 4.3 & 3.4 & 3.5 \\
\hline $2011 / 12$ & 10.0 & & & $\frac{9.4}{9.0}$ & $\begin{array}{l}1.1 \\
7.7\end{array}$ & 8.0 & 9.0 & 8.4 & & 4.2 & $\begin{array}{l}5.0 \\
5.7\end{array}$ & 3.2 & 6.6 & 3.6 & 3.0 & 1.7 \\
\hline $2012 / 13$ & 10.8 & & & 9.1 & 7.9 & 8.9 & 8.4 & & & 5.6 & 6.7 & 4.6 & 5.9 & 4.7 & 3.8 & 3.6 \\
\hline $2013 / 14$ & 9.2 & & & 3.9 & 3.5 & 2.7 & 3.2 & & & 1.1 & 1.2 & 0.7 & 1.7 & 0.7 & 0.6 & 0.7 \\
\hline $2014 / 15$ & 9.4 & & & 6.7 & 6.2 & 5.7 & 6.2 & & & 2.0 & 3.1 & 1.5 & 3.4 & 2.3 & 1.4 & 1.0 \\
\hline $2015 / 16$ & 8.3 & & & 5.2 & 3.2 & 4.7 & 5.6 & & & 2.5 & 2.9 & 1.8 & 1.4 & 1.5 & 1.3 & 1.0 \\
\hline Average & 10.5 & 10.1 & 7.6 & 8.6 & 6.6 & 7.8 & 8.0 & 7.4 & 6.7 & 4.0 & 4.9 & 3.3 & 5.5 & 4.0 & 2.8 & 2.5 \\
\hline$\delta$ & 1.41 & 1.67 & 1.68 & 1.82 & 2.10 & 1.95 & 1.90 & 1.76 & 1.62 & 1.55 & 1.95 & 1.49 & 2.05 & 1.49 & 1.10 & 1.18 \\
\hline CV [\%] & 13.5 & 16.6 & 22.2 & 21.1 & 31.8 & 24.9 & 23.7 & 23.8 & 24.1 & 38.8 & 40.3 & 44.9 & 37.0 & 36.9 & 40.0 & 47.4 \\
\hline $\begin{array}{c}\text { N_Snow } \\
y \text { winters } \\
{[\%]}\end{array}$ & 16.4 & 12.2 & 12.1 & 15.7 & 18.2 & 14.5 & 14.5 & 13.7 & 16.7 & 12.7 & 6.7 & 9.1 & 16.4 & 10.9 & 12.7 & 10.9 \\
\hline $\begin{array}{c}\text { N_Little } \\
\text { snow } \\
\text { winters } \\
\text { [\%] }\end{array}$ & 18.2 & 17.1 & 15.2 & 15.7 & 22.7 & 18.2 & 14.5 & 15.7 & 16.7 & 16.4 & 20.0 & 18.2 & 20.0 & 18.2 & 20.0 & 14.5 \\
\hline
\end{tabular}

Explanations:

a blue field indicates a snowy winter $(\mathrm{WSW} \geq \mathrm{WSWavg}+\delta)$;

a red field indicates a winter with little snow (WSW $\leq$ WSWavg- $\delta$ );

a white field indicates a moderately snowy winter (WSWavg- $\delta<W S W<W S W a v g+\delta)$.

The blue field indicates a snowy winter (WSW $\geq$ WSWavg $+\delta$ ). The red field indicates a winter with little snow $(W S W \leq W S W a v g-\delta)$. The white field indicates a moderately snowy winter (WSWavg $-\delta<$ WSW $<$ WSWavg $+\delta$ )

frequency of western circulation over Poland (Ustrnul 1998). The increase in winter temperatures may reduce the share of snowfall in overall precipitation, which exhibited an upward trend in the cold half of the year in most regions of Poland in the period from 1930 to 1980 (Kożuchowski 1985). 

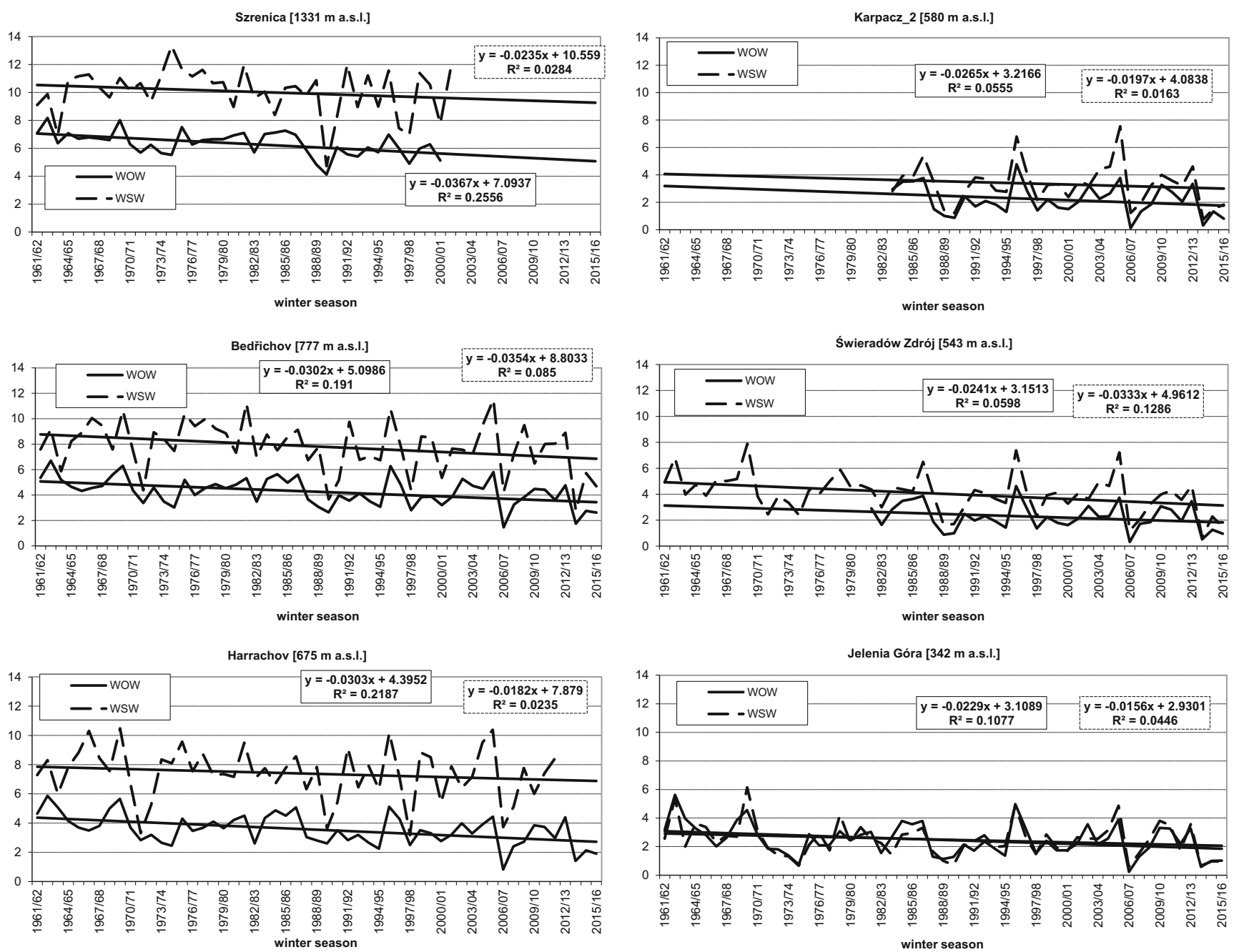

Fig. 8 Winter severity (WOW) and snowiness (WSW) indices charted alongside their trend lines (bold black line) and simple regression equations at selected stations with southern (left column) and northern (right column) macroexposures

\section{Relationship between the winter severity index and the winter snowiness index}

The analysis of very similar temporal trends in the WOW and WSW indices appears to reveal a relationship between them. This applies to stations with both southern and northern macroexposures (Fig. 8). On this basis, and owing to the relatively high correlation coefficient (ca. 0.8 ), conclusions on the relationship between the WOW and WSW indices have been drawn in the Biebrza River valley (Olba-Zięty and Grabowski 2007) and in Warsaw (Majewski et al. 2011).

However, when the WOW-WSW correlation is presented in the form of an XY chart, the apparently close association is no longer as pronounced. Depending on the station, correlation coefficients range from $0.3-0.4$ in the upper range of the mountains to ca. $0.85-0.87$ at low-altitude stations. There is also a clear variation in the correlation coefficient $(R)$ between the WOW and WSW indices depending on the macroexposure and altitude above sea level (Fig. 9). Namely, stations with southern macroexposure (e.g. Bedřichov, Harrachov) exhibit markedly lower $R$ values than stations with northern macroexposure (e.g. Karpacz, Świeradów Zdrój, Jelenia Góra). Thus, at stations with northern macroexposure on the slopes of the Karkonosze Mountains and Jizera Mountains, WOW and WSW values are more correlated than at stations with southern macroexposure. This means that on the northern slopes, an increase in WOW index values almost always results in an increase in WSW index values, while on the southern slopes, this pattern is much less frequent. In addition, the range of WSW index variability on the southern slopes is higher than on the northern slopes. However, the correlation is positive, and the relationship is directly proportional in both cases. The situation is slightly different for stations that are situated in the upper ranges (Mount Śnieżka and Mount Szrenica) where this relationship is the weakest. This is caused by the high prevalence of strong and very strong winds, which blow snow from one side of the mountain massif to the other. For example, average annual wind speeds on Mount Śnieżka 
Szrenica [1331 m a.s.l.]

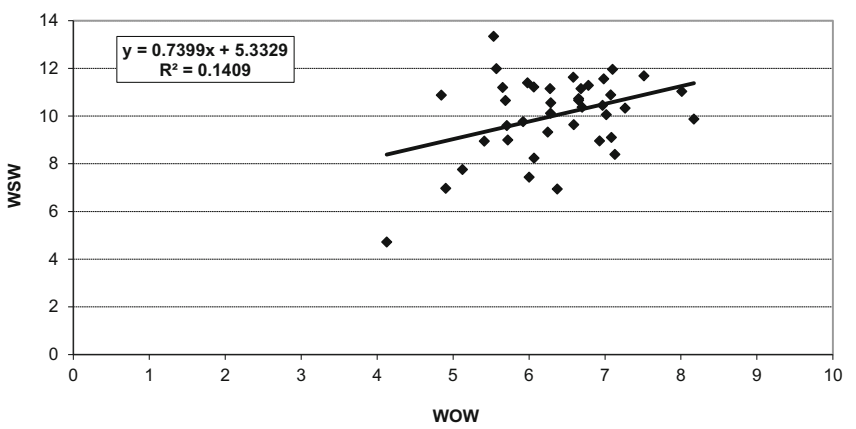

Bedrichov [777 m a.s.l.]

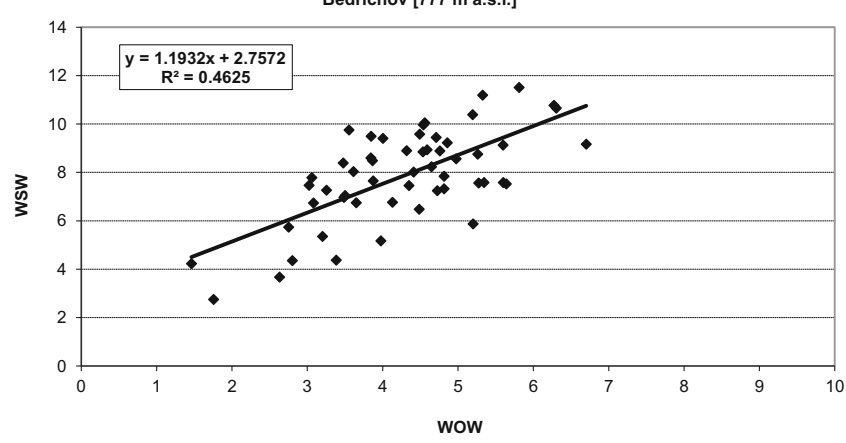

Harrachov [675 m a.s.I.]

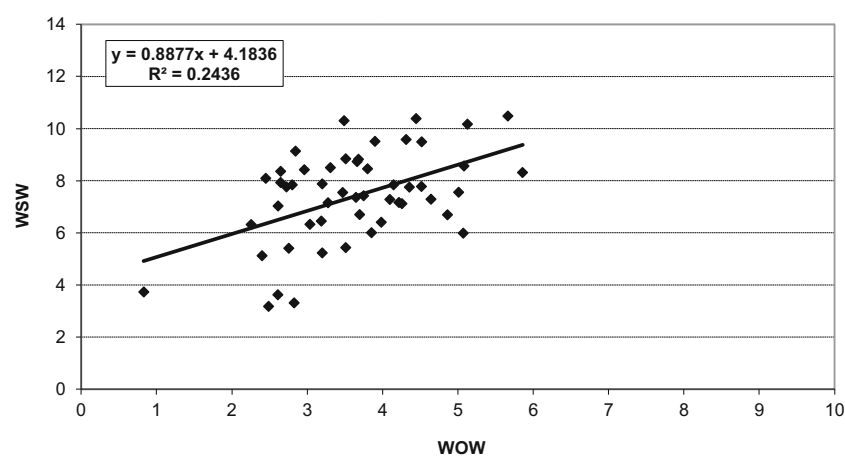

Karpacz_2 [580 m a.s.I.]

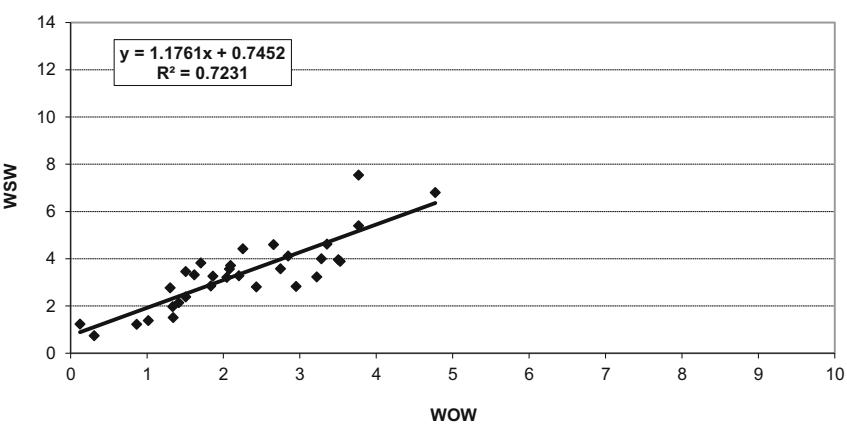

Świeradów Zdrój [543 m a.s.l.]

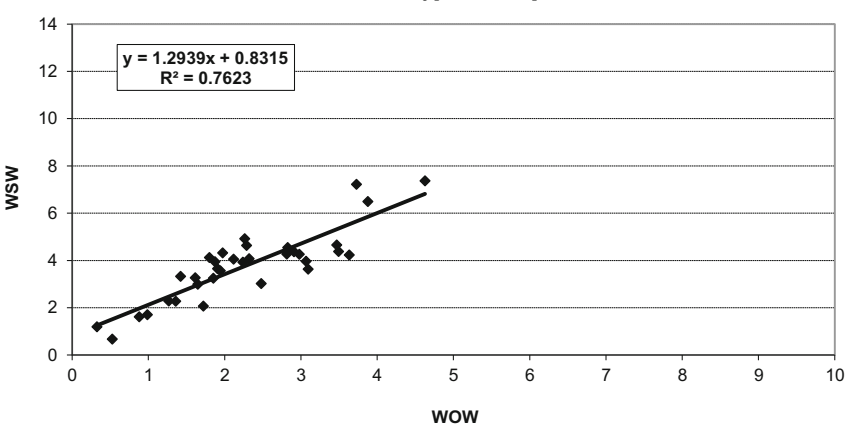

Jelenia Góra [342 $m$ a.s.l.]

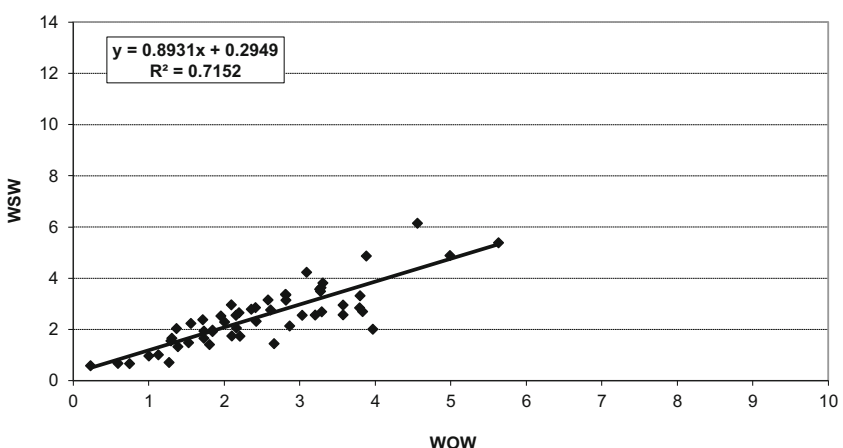

Fig. 9 Relationship between winter severity (WOW) and snowiness (WSW) indices charted alongside their trend lines (bold black line) and simple regression equations at selected stations with southern (left column) and northern (right column) macroexposures

and Mount Szrenica reach 12.2 and $9.5 \mathrm{~m} / \mathrm{s}$, respectively. Thus, the upper ranges of the Karkonosze Mountains are among the most windy locations in continental Europe (Głowicki 1995; Sobik et al. 2014). The average annual prevalence of very strong winds (with speed of over $15 \mathrm{~m} / \mathrm{s}$ ) on Mount Śnieżka is $61 \%$, and in January, it is as high as $76 \%$ (Głowicki 1995).

Snow cover studies in the Swiss Alps have demonstrated that there appears to be no clear-cut relationship between snow cover retention time and air temperature. The nature of this relationship depends on the type of winter. Milder winters are usually associated with higher precipitation than colder ones (Beniston et al. 2003). Thus, in spite of the considerable variability of snow cover in subsequent years and the increase in air temperatures, average long-term climatic conditions in the Swiss Alps in the twentieth century were conducive to long snow cover retention times. This is due, inter alia, to the fact that mild winters are associated with an increase in snowfall in high locations, and rain in lower ones (Laternser and Schneebeli 2003). Nevertheless, any change in one or both of these factors may lead to significant changes in snow cover retention time (Beniston et al. 2003). The indirect influence of temperature conditions, which affect type (solid, liquid) of precipitation, on snow cover in the Carpathians was pointed out by Obrębka-Starklowa et al. (1995). Earlier, Bultot et al. (1994) demonstrated that a decrease in snowfall retention time with increase in air temperature was highest at altitudes lower than $600 \mathrm{~m}$ a.s.1.

\section{Summary and conclusions}

The analysis of temperature and snow conditions in the Karkonosze Mountains and Jizera Mountains, which was 
conducted on the basis of modified multicomponent formulas proposed by Paczos (1982), enables us to put forward the following claims:

- the orientation of the main ridge of the Karkonosze Mountains (along the WNW-ESE axis) and of the Jizera Mountains, which are oblique to the Karkonosze ridge, in relation to the predominant western circulation in winter, is an important factor affecting the thermal characteristics of air masses around these massifs;

- Stations located on the northern side of the mountains, below the ridge zone, are subject to the warming effect of foehn winds during the cold season. This effect increases together with the difference in altitude between the ridge and the station in question;

- In winter, stations in the lower and middle parts of slopes with northern macroexposure are, on average, one WOW class warmer than stations with southern macroexposure located at comparable altitudes above sea level;

- The spatial distribution of the average WOW index value is related to the absolute altitude of the station both on the northern and southern sides of the mountains;

- Trends in the WOW winter severity index calculated for all stations analysed in the Karkonosze Mountains and Jizera Mountains are negative. The decreasing WOW values indicate a progressive increase in air temperatures and in individual thermal indicators (WOW components), and consequently, climate warming.

- Moderate winters predominate, but in recent decades, the frequency of mild winters has increased;

- Southern and western (windward) slope macroexposure is conducive to better snow conditions than those on slopes with northern macroexposure, which are leeward in relation to the prevailing winter circulation from the west and southwest;

- the spatial variability of the average WSW in the Karkonosze Mountains and Jizera Mountains results from multiple factors, including altitude above sea level and the orographic deformation of the field through which air masses flow. As a result of this deformation, there is a clear contrast in snow conditions between the catchment of the Elbe River (SW and $\mathrm{W}$ macroexposure) relative to the catchment of the Odra River (NE and $\mathrm{N}$ macroexposure). Areas with SW and W macroexposures exhibit better snow conditions. This contrast is particularly noticeable in the 500-900 $\mathrm{m}$ a.s.1. range. The snow conditions typical of the slope zone in the Elbe River catchment are present in the Odra River catchment at altitudes that are approx. $250 \mathrm{~m}$ higher up. In the upper mountain ranges, the differences are blurred owing to the frequent alternating movement of snow, which is carried by the wind from one side of the massif to the other.
- Average WSW index values exhibit much greater spatial variability than WOW index values;

- Trends in the WSW index at all stations analysed were negative and in most cases insignificant at the 0.05 significance level;

- Moderately snowy winters predominate, but in recent decades, the frequency of winters with little snow has increased;

- Variation in the WOW and WSW indices is inversely proportional to the station's altitude;

- The meridional circulation component is much more important than the zonal one in determining the temperature and snowiness of winters in the study area;

- The trends in winter temperature and snowiness as expressed by the WOW and WSW indices are in line with the trends observed in other mountain areas of Poland and Europe as evidenced by the literature on the subject cited in this paper;

- The correlation between the WOW and WSW indices is positive (directly proportional);

- At stations with northern macroexposure, the WOW and WSW indices are more strongly correlated than at ones with southern macroexposure. This relationship is the weakest at stations that are situated in the upper ranges (Mount Śnieżka and Mount Szrenica). This is caused by the high prevalence of very strong winds, which blow snow from one side of the mountain massif to the other.

The results of this research may provide the basis for further studies on snow cover and on temperature conditions in mountain areas in Poland, and are in line with the trends observed in other European mountain ranges.

Open Access This article is distributed under the terms of the Creative Commons Attribution 4.0 International License (http:// creativecommons.org/licenses/by/4.0/), which permits unrestricted use, distribution, and reproduction in any medium, provided you give appropriate credit to the original author(s) and the source, provide a link to the Creative Commons license, and indicate if changes were made.

\section{References}

Bednorz E (2004) Snow cover in eastern Europe in relation to temperature, precipitation and circulation. Int J Climatol 24:591-601. https://doi.org/10.1002/joc.1014

Bednorz E (2008) Synoptics reason for heavy snowfalls in the PolishGerman lowlands. Theor Appl Climatol 92:133-140. https://doi. org/10.1007/s00704-007-0322-4

Bednorz E (2013) Synoptic conditions of heavy snowfalls in Europe. Geogr Ann Ser A 95:67-78. https://doi.org/10.1111/geoa.12001

Beniston M (1997) Variations of snow depth and duration in the Swiss Alps over the last 50 years: links to changes in large-scale climatic 
forcings. Clim Chang 36:281-300. https://doi.org/10.1007/978-94015-8905-5 3

Beniston M (2000) Environmental change in mountains and uplands. Arnold, London, pp 172

Beniston M, Keller F, Goyette S (2003) Snow pack in the Swiss Alps under changing climatic conditions: an empirical approach for climate impacts studies. Theor Appl Climatol 74:19-31. https://doi. org/10.1007/s00704-002-0709-1

Brown RD, Petkova N (2007) Snow cover variability in Bulgarian mountainous regions, 1931-2000. Int J Climatol 27:1215-1229. https:// doi.org/10.1002/joc. 1468

Bultot F, Gellens D, Schädler B, Spreafico M (1994) Effect of climate change on snow accumulation and melting in the Broye catchment (Switzerland). Clim Chang 28:339-363. https://doi.org/10.1007/ bf01104078

Cayan DR (1996) Interannual climate variability and snow-pack in the Western United States. J Clim 9:928-948. https://doi.org/10.1175/ 1520-0442(1996)009<0928:icvasi>2.0.co;2

ČMeS (2016) Meteorologický slovník výkladový a terminologický (eMS). version eMS 1.4 (3/2016) http://slovnik.cmes.cz. Accessed 22 May 2017

Dettinger MD, Cayan DR (1995) Large-scale atmospheric forcing of recent trends toward early snowmelt runoff in California. J Clim 8(3):606-623. https://doi.org/10.1175/1520-0442(1995)008<0606: lsafor $>2.0 . \mathrm{co} ; 2$

Domonkos P, Piotrowicz K (1998) Winter temperature characteristics in Central Europe. Int J Climatol 18:1405-1417. https://doi.org/10. 1002/(sici)1097-0088(19981115)18:13<1405::aid-joc323>3.0.co;2-d

Falarz M (2000-2001) Zmienność wieloletnia wystepowania pokrywy śnieżnej w polskich Tatrach (Long-term variability of snow cover in polish part of Tatra Mountains). Folia Geogr Seria: Geogr-Phys 31-32:101-123 (in Polish)

Falarz M (2002) Klimatyczne przyczyny zmian i wieloletniej zmienności występowania pokrywy śnieżnej w polskich Tatrach (The climatic causes of changes and long-term variability in the snow cover of the Polish Tatra Mountains). Przegl Geogr 74(1):83-107 (in Polish)

Falarz M (2004) Variability and trends in the duration and depth of snow cover in Poland in the 20th century. Int J Climatol 24(13):17131727. https://doi.org/10.1002/joc.1093

Falarz M (2006) Wykrywanie i korekta niejednorodności wieloletnich serii niwalnych (Detection and correction of inhomogeneity in the long-term snow cover series). Ann Univ Mariae Curie-Sk LXI 18: 155-163 (in Polish)

Foster J, Owe M, Rango A (1983) Snow cover and temperature relationships in North America and Eurasia. J Clim Appl Meteorol 22:460 469. https://doi.org/10.1175/1520-0450(1983)022<0460:scatri $>2.0$. $\mathrm{co} ; 2$

Głowicki B (1970) O niektórych cechach mikroklimatu Kotliny Jelenigórskiej (Some aspects of microclimate of Jelenia Góra valley). Rocz Jeleniogórski 8:147-160 (in Polish)

Głowicki B (1993) Zmienność termicznych pór roku w Karkonoszach (Variability of the thermal seasons in the Karkonosze Mountains). In: Tomaszewski J (ed) Geoekologiczne Problemy Karkonoszy (Geoecological problems of the Karkonosze Mountains). Materiały z sesji naukowej w Karpaczu 11-13.X.1991, pp 21-28 (in Polish)

Głowicki B (1995) Klimat Śnieżki (Climate of Mt. Śnieżka). In: Dubicki A, Głowicki B (eds) Wysokogórskie Obserwatorium Meteorologiczne na Śnieżce. Biblioteka Monitoringu Środowiska, Wrocław, pp 37-64 (in Polish)

Głowicki B (2005) Klimat Karkonoszy (Climate of the Karkonosze Mountains). In: Mierzejewski M (ed) Karkonosze - przyroda nieożywiona i człowiek. Wydawnictwo UWr, Wrocław, pp 381397 (in Polish)

Haeberli W, Beniston M (1998) Climate change and its impacts on glaciers and permafrost in the Alps. Ambio 27:258-265
Hantel M, Ehrendorfer M, Haslinger A (2000) Climate sensitivity of snow cover duration in Austria. Int J Climatol 20:615-640. https:// doi.org/10.1002/(sici)1097-0088(200005)20:6<615::aid-joc489>3. $0 . \operatorname{co} ; 2-0$

Hess M (1965) Piętra klimatyczne w polskich Karpatach Zachodnich (Vertical climatic zones in the Polish Western Carpathians). Zeszyty Naukowe UJ. Pr Geol 11:1-262 (in Polish)

Hess M (1974) Klimat Krakowa (Climate of Cracow). Folia Geogr Seria: Geogr-Phys 8:45-102 (in Polish)

Hess M, Niedźwiedź T, Obrębka-Starklowa B (1980) O prawidłowościach piętrowego zróżnicowania stosunków klimatycznych w Sudetach (On regularities in zonal differentiation of the climatic conditions in the Sudety Mountains). Rocznik Naukowo-Dydaktyczny Wyższej Szkoły Pedagogicznej w Krakowie 71:167-201 (in Polish)

Hidalgo HG, Das T, Dettinger MD, Cayan DR, Pierce DW, Barnett TP, Bala G, Mirin A, Wood AW, Bonfils C, Santer BD, Nozawa T (2009) Detection and attribution of streamflow timing changes to climate change in the Western United States. J Clim 22(13):38383855. https://doi.org/10.1175/2009jcli2470.1

Huang J, van den Dool HM, Barnston AG (1996) Long-lead seasonal temperature prediction using optimal climate normals. J Clim 9: 809-817. https://doi.org/10.1175/1520-0442(1996)009<0809: 1lstpu>2.0.co;2

IPCC (2001) Climate change. The IPCC Third Assessment Report, vol Volumes I (Science), II (Impacts and Adaptation) and III (Mitigation Strategies). Cambridge University Press, Cambridge

IPCC (2013) Climate change. The IPCC Fifth Assessment Report, vol Volumes I (Science). Cambridge University Press, Cambridge

Jackson MC (1977) A classification of the snowiness of 100 winters-a tribute to the late LCW Bonacina. Weather 32(3):91-98. https://doi. org/10.1002/j.1477-8696.1977.tb04523.x

Janasz J (2000) Warunki termiczne i śnieżne zim w Lublinie (1960/611994/95) (Thermic and snow conditions of winters in Lublin (1960/61-1994/95)). Acta Agrophysica 34:71-78 (in Polish)

Janiszewski F (1988) Instrukcja dla stacji meteorologicznych (Instruction for weather stations). Wydawnictwa Geologiczne, Warszawa 264 pp (in Polish)

Karl TR, Groisman PY, Knight RW, Heim RR (1993) Recent variations of snow cover and snowfall in North America and their relation to precipitation and temperature variations. J Clim 6:1327-1344. https://doi.org/10.1175/1520-0442(1993)006<1327:rvosca>2.0.co;

Klein G, Vitasse Y, Rixen C, Marty C, Rebetez M (2016) Shorter snow cover duration since 1970 in the Swiss Alps due to earlier snowmelt more than to later snow onset. Clim Change. https://doi.org/10. 1007/s10584-016-1806-y

Kliegrová S, Metelka L, Materna J (2009) Mění se klima Krkonoš? (Is climate of the Karkonosze mountains changing?). Krkonoše Jizerské hory 3:24-25 (in Czech)

Kożuchowski K (1985) Zmienność opadów atmosferycznych w Polsce w stuleciu 1881-1980 (Variation in precipitation in the years 18811980 in Poland). Acta Geogr Lodziensia 48:1-158 (in Polish)

Kożuchowski K, Żmudzka E (2001) Ocieplenie w Polsce: skala i rozkład sezonowy zmian temperatury powietrza $\mathrm{w}$ drugiej połowie XX wieku (The warming in Poland: the range and seasonality of the changes in air temperature in the second half of 20th century). Przegl Geofizyczny 46(1-2):81-90 (in Polish)

Kulasová A, Bubeníčková L (2009) Podnebí a počasí Jizerských hor. In: Karpaš $\mathrm{R}$ et al (eds) Jizerské hory, $\mathrm{O}$ mapách, kamení a vodě. Nakladatelství RK, Liberec, pp 344-371 (in Czech)

Kuziemska D (1983) O zakresie zmienności temperatury powietrza w Polsce (On the range of the air temperature variability in Poland). Przegl Geofizyczny 3-4:329-343 (in Polish)

Kwiatkowski J (1972) Feny w Kotlinie Jeleniogórskiej (Foehns in Jelenia Góra valley). Acta Univ Wratislav 173:3-46 (in Polish) 
Kwiatkowski J (1975) Zasięg fenów sudeckich i ich wpływ na mezoklimat regionów południowo-zachodniej i środkowej Polski (The Reach of Sudeten Foehns and their influence on the Mezoclimate of southwestern and central regions of Poland). Przegl Geofizyczny 20(28):1 15-30 (in Polish)

Kwiatkowski J (1979) Zjawiska fenowe w Sudetach i na przedpolu Sudetów (Foehn phenomena in the Sudetes and in the Sudetian foreland). Probl Zagosp Ziem Górs 20:243-280 (in Polish)

Kwiatkowski J (1985) Szata śnieżna, szadź i lawiny (Snow cover, Rime and Avalanches). In: Jahn A (ed) Karkonosze Polskie (The Polish Karkonosze Mountains). Wrocław, pp 117-144 (in Polish)

Lapin M, Faško P, Pecho J (2007) Snow cover variability and trends in the Tatra Mountains in 1921-2006. In: Proceedings of the 29th International Conference on Alpine Meteorology Chambéry. France 4-6 June 2007

Laternser M, Schneebeli M (2003) Long-term snow climate trends of the Swiss Alps (1931-99). Int J Climatol 23:733-750. https://doi.org/ 10.1002/joc. 912

Lipina P, Kain I, Žídek D (2014) Návod pro pozorovatele automatizovaných meteorologických stanic. Metodický předpis č. 2. ČHMÚ, Praha (in Czech)

Luterbacher J, Liniger MA, Menzel A, Estrella N, Della-Marta PM, Pfister C, Rutishauser T, Xoplaki E (2007) Exceptional European warmth of autumn 2006 and winter 2007: historical context, the underlying dynamics, and its phonological impacts. Geophys Res Lett 34:L12704. https://doi.org/10.1029/2007GL029951

Majewski G, Gołaszewski D, Przewoźniczuk W, Rozbicki T (2011) Warunki termiczne i śnieżne zim w Warszawie w latach 1978/79 2009/10 (Thermal and snow conditions of winters in Warsaw 1978/79-2009/10). Prace i Studia Geogr 47:147-155 (in Polish)

Marty C (2008) Regime shift of snow days in Switzerland. Geophys Res Lett 35:L12501. https://doi.org/10.1029/2008GL033998

Marty C (2011) Snow cover changes in the alps. In: Singh VP, Singh P, Haritashya UK (eds) Encyclopedia of snow, ice and glaciers. Part of the series Encyclopedia of Earth Sciences Series. Springer Netherlands, Netherlands, pp 1036-1038. https://doi.org/10.1007/ 978-90-481-2642-2 612

Mayes Boustead BE, Hilberg SD, Shulski MD, Hubbard KG (2015) The accumulated winter season severity index (AWSSI). J Appl Meteor Climatol 54:1693-1712. https://doi.org/10.1175/JAMC-D-14-0217.1

Migała K (2005) Piętra klimatyczne w górach Europy a problem zmian globalnych (Climatic belts in the European Mountains and the issue of global changes). Studia Geograficzne 78, Wrocław, pp 149 (in Polish)

Migała K, Urban G, Tomczyński K (2016) Long-term air temperature variation in the Karkonosze mountains according to atmospheric circulation. Theor Appl Climatol 125:337-351. https://doi.org/10. 1007/s00704-015-1468-0

Němec L, Zusková I (2005) Změny sněhové pokrývky v České republice od roku 1926 (Changes in snow cover in the Czech Republic since 1926). Meteorologické Zprávy (Meteorol Bull) 58(5):135-138 (in Czech)

Niedźwiecki M (1998) Charakterystyka pokrywy śnieżnej w Łodzi w latach 1950-1989 (The charakteristic of snow cover in Łódź in the period 1950-1989). Acta Univ Lodz 3:265-277

Niedźwiedź T, Bąbka M, Borkowski J, Cebulak E, Czekierda D, Dziewulska-Łosiowa A, Falarz M et al (2003) In: KossowskaCezak U, Niedźwiedź T, Paszyński J (ed) Słownik meteorologiczny (Glossary of meteorology). IMGW, Warszawa, pp 495

Obrębka-Starklowa B, Bednarz Z, Niedźwiedź T, Trepińska J (1995) On the trends of the climatic changes in the higher parts of the Carpathian Mountains. Zeszyty Naukowe UJ. Prace Geogr 95: 123-151

Ojrzyńska H, Błaś M, Kryza M, Sobik M, Urban G (2010) Znaczenie lasu oraz morfologii terenu w rozwoju pokrywy śnieżnej w Sudetach Zachodnich na przykładzie sezonu zimowego 2003/2004 (The role of forest and terrain morphology in snow cover development in the
Western Sudety - 2003/2004 winter season case study). Sylwan 154(6):412-428 (in Polish)

Olba-Zięty E, Grabowski J (2007) Warunki termiczne i śnieżne zim doliny Biebrzy w latach 1980/1981-2004/2005 (Thermal and snowy condition of Winters in Biebrza Valley during 1980/812004/2005). Acta Agrophysica 10(3):625-634 (in Polish)

Paczos S (1982) Stosunki termiczne i śnieżne zim w Polsce (Thermal conditions and snowiness of Winters in Poland). Rozprawy hab., UMCS, Lublin, p 24 (in Polish)

Paczos S (1985) Zagadnienie klasyfikacji zim w świetle różnych kryteriów termicznych (Classification of Winters in the Light of Various Thermic Criteria). Ann UMCS 40(7):133-155 (in Polish)

Piasecki J (1995) Pokrywa śnieżna na Szrenicy w latach 1960-1990 i klasyfikacja śnieżności zim (The snow cover on the Szrenica Mountain during 1960-1990). Acta UWr Prace Inst Geogr Ser C 1705:23-57 (in Polish)

Piotrowicz K (1997) Thermal differentiation of winters in the Carpathian Mountains altitudinal profile during the period 1961/62-1990/91. Geogr Pol 70:89-100

Piotrowicz K (2004) Temperatura okresu zimowego jako wskaźnik zmian klimatu (Winter period Temperature as a Climate change index). In: Haladyn K, Mikłaszewski A, Radomski R, Ropuszyński P, Wojtyszyn B (ed) Klimat-środowisko-człowiek (Climate-environment-man). Polski Klub Ekologiczny, Wrocław, pp 23-31 (in Polish)

Piotrowicz K (2006) Kryteria wyznaczania ekstremalnych zim (Extreme winters setting criterions). Ann Univ Mariae Curie-Sk LXI 42:362369

Príbullová A, Pecho J, Bíčárová S (2009) Analysis of snow cover at selected meteorological stations in the High Tatra Mountains. In: Príbullová A and Bíčárová S (ed) Sustainable Development and Bioclimate. Reviewed Conference Proceedings. Stará Lesná:56-57

Rebetez M, Reinhard M (2008) Monthly air temperature trends in Switzerland 1901-2000 and 1975-2004. Theor Appl Climatol 91: 27-34. https://doi.org/10.1007/s00704-007-0296-2

Sansom J, Tait A (2004) Estimation of long-term climate information at locations with short-term data records. J Appl Meteorol 43:915-923. https://doi.org/10.1175/1520-0450(2004)043<0915:EOLCIA>2.0. $\mathrm{CO} ; 2$

Scherrer SC, Appenzeller C, Laternser M (2004) Trends in Swiss Alpine snow days: the role of local and large scale climate variability. Geophys Res Lett 31:L13215. https://doi.org/10.1029/ 2004GL020255

Schmuck A (1969) Klimat Sudetów (The climate of the Sudetes). Probl Zagosp Ziem Górs 5(18):93-153 (in Polish)

Schönwiese CD, Rapp J (1997) Climate trend atlas of Europe based on observations 1891-1990. Kluwer Academic Publishers, Dordrecht

Sobik M, Błaś M, Migała K, Godek M, Nasiółkowski T (2014) Klimat (Climate). In: Knapik R, Raj A (ed) Przyroda Karkonoskiego Parku Narodowego (The nature of the Karkonosze National Park). Jelenia Góra, pp 147-186 (in Polish)

Sobik M, Urban G (2000) Warunki termiczne zlewni Kamionka w Górach Izerskich (Thermal conditions of the Kamionek Catchment in the Izerskie Mountains). Acta UWr 2269(LXXIV):143-157 (in Polish)

Sobik M, Urban G, Błaś M, Kryza M, Tomczyński K (2009) Uwarunkowania zalegania pokrywy śnieżnej w Sudetach Zachodnich w sezonach zimowych 2001/2002-2005/2006 (Determinants of snow cover in the winter seasons in Western Sudety Mountains during 2001/2002-2005/2006). Wiad Meteorol Hydrol Gosp Wodnej 2-3:31-47 (in Polish)

Srivastava AK, Guhathakurta P, Kshirsagar SR (2003) Estimation of annual and seasonal temperatures over Indian stations using optimal normals. Mausam 54:615-622

Stewart IT, Cayan DR, Dettinger MD (2004) Changes in snowmelt runoff timing in Western North America under a 'Business as Usual' Climate Change Scenario. Clim Chang 62(1-3):217-232. https:// doi.org/10.1023/B:CLIM.0000013702.22656.e8 
Stewart IT, Cayan DR, Dettinger MD (2005) Changes toward earlier streamflow timing across Western North America. J Clim 18(8): 1136-1155. https://doi.org/10.1175/jcli3321.1

Trepińska J (1976) Mild winters in Cracow against the background of the contemporary circulation processes. Geogr Pol 33:97-105

Twardosz R, Kossowska-Cezak U (2016) Exceptionally cold and mild winters in Europe (1951-2010). Theor Appl Climatol 125:399-411. https://doi.org/10.1007/s00704-015-1524-9

Urban G (2002) Warunki termiczne obszarów mrozowiskowych Gór Izerskich $\mathrm{i}$ ich wpływ na wzrost lasu (The thermal conditions of frost areas of Izera Mountains and their influence on growth forest). Dissertation, University of Wrocław, pp 165 (in Polish)

Urban G (2010) Ocena wybranych metod obliczania średniej dobowej, miesięcznej i rocznej wartości temperatury powietrza (na przykładzie Sudetów Zachodnich i ich przedpola) (Evaluation of selected methods of calculating the daily, monthly and annual mean air temperature (with the Western Sudety Mountains and their foreland as an example)). Opera Corcon 47(1):23-33

Urban G (2013) Evaluation of accuracy of selected methods of calculation of the daily mean air temperature depending on atmospheric circulation (the case study of the Western Sudety Mountains and their foreland). Opera Corcon 50/S:81-96

Urban G (2015) Zaleganie pokrywy śnieżnej i jego zmienność w polskiej części Sudetów i na ich przedpolu (Duration of snow cover and its variability in the Polish part of the Sudetes Mts. and their foreland). Przegl Geogr 87(3):497-516. https://doi.org/10.7163/PrzG.2015.3. 5 (in Polish)
Urban G (2016) Snow cover and its variability in the Polish Sudetes Mts. and the Sudetic Foreland. Geografie 121(1):32-53

Urban G, Richterová D (2010) Warunki śniegowe a uprawianie narciarstwa w Sudetach Zachodnich na polsko-czeskim pograniczu (Snow conditions and skiing in Western Sudety on Polish-Czech Republic border). Wiad Meteorol Hydrol Gospod Wod 1-4:3-28 (in Polish)

Urban G, Richterová D, Vajskebr V (2011) Pokrywa śnieżna w październiku 2009 w Sudetach Zachodnich jako przykład zjawiska ekstremalnego (Snow cover in October 2009 in the Western Sudety Mountains as an example of extreme phenomenon). Wiad Meteorol Hydrol Gospod Wod 5(4):75-96 (in Polish)

Urban G, Tomczyński K (2017) Air temperature trends at Mount Śnieżka (Polish Sudetes) and solar activity, 1881-2012. Acta Geogr Sloven 57-2:33-44. https://doi.org/10.3986/AGS.837

Ustrnul Z (1998) Variability of air temperature and circulation at selected stations in Europe. In Proceedings of the 2nd European Conference on Applied Climatology. Österreichische Beitra"ge zu Meteorologie und Geophysik. Zentralanstalt für Meteorologie und Geodynamik, Vienna, 19; 81 (full text on ECAC CD-ROM, session 1)

Wibig J, Głowicki B (2002) Trends of minimum and maximum temperature in Poland. Clim Res 20(2):122-133. https://doi.org/10.3354/ cr020123

WMO (2011) Characterizing climate from datasets. In: Guide to Climatological Practices, World Meteorological Organization, Geneva, pp. 54-72 updated 19.01.2016 http://www.wmo.int/ pages/prog/wcp/wcdmp/GCDS_1.php. Accessed 22 May 2017 